Estonian Journal of Archaeology, 2021, 25, 2, 182-213

https://doi.org/10.3176/arch.2021.2.05

\author{
Marcus Adrian Roxburgh
}

\title{
TIME MACHINES; AN EXPLORATION OF ROMAN PERIOD COPPER-ALLOY OBJECTS IN AN ESTONIAN TARAND CEMETERY, USING pXRF
}

Received 4 July 2021, accepted 24 August 2021, available online 3 November 2021

This paper presents a new qualitative method for the use of $\mathrm{pXRF}$ in archaeological research. A bulk, multi-elemental approach applies a non-destructive survey technique to the copperalloy objects recovered in a Roman period tarand cemetery, in north-east Estonia. The aim is to explore the chronological development of the cemetery by comparing the objects and their find locations against historically known changes in alloy composition. Then a more focused destructive analysis is undertaken from a selected group of bracelets commonly found in these northerly cemeteries, but also in greater numbers in the Roman provinces.

The results revealed strong correlations between alloy classification and find location. Furthermore, the quantitative (destructive) analysis of a single bracelet has added to the debate about the nature of long-distance contact between the people of north-eastern Estonia, the southern Baltic and the distant Roman frontier. It also raises the possibility that these people were placing Roman produced items into their cemeteries in the decades before the traditionally accepted start of the Roman Iron Age. This suggests that a new assessment for its beginning is called for, one that aligns the earliest imported Roman items to the first half of the 1st century AD.

Marcus Adrian Roxburgh, Research Fellow in Archaeology, Department of Archaeology, University of Tartu, 2 Jakobi St., 50090 Tartu, Estonia; marcus.adrian.roxburgh@ut.ee

The characterisation of corroded copper-alloy objects, including the application of portable X-ray fluorescence spectrometry (pXRF) has been having some success in recent years (Bayley \& Butcher 2004; Pollard et al. 2015; Olli \& Roxburgh 2018; Roxburgh et al. 2018; Roxburgh \& Olli 2019). This is especially true for objects from the Roman period, which saw two chemically different copper-alloys (bronze and brass) enjoy widespread circulation (see Craddock 1978; Baumeister 2004). The current paper presents an innovative new approach for the use of pXRF in archaeological research in that it attempts to identify, then plot these different alloy 
types into an archaeological context. The aim is to explore the chronological development of a tarand cemetery in north-eastern Estonia, which are formed from rows of rectangular or subrectangular stone enclosures that contain both inhumation and cremation burials (for more see Lang 2007, 170-203; Olli 2019). This is done by comparing the typological classifications and find locations of the objects, with historically known changes in alloy composition. Previous studies have shown that many Roman objects, especially brooches were made in brass, a metal possibly reserved initially for use in the fabricate of legionary fortresses (such as at Xanten, Germany. See Rehren 1999). But many other objects were also made in bronze or gunmetal, which is a mixture of the two (for examples see Roxburgh et al. 2017, 185, fig. 5.3.9-5.3.16). This approach is effective for the basic identification of alloy types (Tate 1986, 23), as once interesting alloy groups are identified, the data can be usefully interpreted in a qualitative manner, following the method proposed by Roxburgh et al. (2018; also see Rehren 2002, 146). A more targeted analysis from a selected bracelet group is then applied, in order to gain a comparative measurement for an uncorroded surface. This is to aid a better understanding of their original composition.

There has been a long-standing difficulty with establishing the dates for the construction of tarand cemeteries due to the co-mingled nature of both inhumation and cremation burials and associated objects (Olli 2019, 21). Therefore, the question formulated here is can $\mathrm{pXRF}$ analysis contribute to our understanding of chronological change when applied to these Roman period cemeteries?

\section{Historiography}

In Estonia, in the north-eastern reaches of the Baltic, the Pre-Roman Iron Age (500 BC - $50 \mathrm{AD}$ ) was a period of time and geographic space set aside from the intensifying "Roman" world far to the south. But the Roman Republic and its subsequent Empire was one of the most far-reaching, globalising phenomena in European history (Pitts \& Versluys 2014; Witcher 2017). It had been a republic for over 500 years before Augustus became its first Emperor in $27 \mathrm{BC}$, and its northern expansion had already reached the Rhine and Danube rivers during the 1 st century $\mathrm{BC}$. The northern frontiers and the Roman provinces were well established therefore by the start of Estonia's Roman Iron Age (50 AD - 450 AD). At some point during this period, it is thought that the people of the coastal region of northeastern Estonia established direct contact with the people living in the Vistula River delta area - a coastal region of the southern Baltic, what is now Poland, the Kaliningrad oblast of Russia, and coastal Lithuania (Lang 2007, 259). This connection was already attracting scholarly attention as early as the late 19th century (e.g. Grewingk 1877; Hausmann 1896; Hackman 1905), but the importance of the cultural and economic nature of these contacts was particularly stressed in 1923 by Marta Schmiedehelm (1923) developing on Hackmans earlier work. 
Archaeologically speaking this connection is at odds with the rest of Estonia because the tarand grave tradition originates in this north-eastern region and only spreads to other regions during the 2nd-3rd centuries AD (Lang 2007, 203). The reason for this difference, especially at the beginning of the Roman Iron Age is thought to be related to differences in economic practices (ibid. 263). Unlike the rest of Estonia, this north-eastern part was rich in agricultural land, which had become the cornerstone of the local economy by the end of the Pre-Roman Iron Age, whereas the rest was still forested (Schmiedehelm 1955, 5). This difference is thought to have been a major factor in the area as it developed its own separate cultural traditions. These connections become very significant during the later Roman Iron Age, as the other local societies in Estonia gradually adopted northeastern customs (Lang 2007, 265).

One of the key objects that defines this change in Estonia is the introduction of the 'eye' brooch. This is the first brooch of any type to enter the region, very possibly as an import from the northern Roman provinces (Roxburgh \& Olli 2019, 227). Concurrently a new bracelet form, bearing end-knobs, can also trace its provenance to the Vistula area. In contrast these new items can be found alongside older copper alloy objects such as serial ring bracelets whose tradition is more local and whose origin dates from the Pre-Roman Iron Age - although they are more frequently found in 1st-2nd century contexts (Lang 2007, 212, fig. 134: 2).

These new object types were made of copper-alloy and as these objects tend to survive rather well in the archaeological record, they have received much attention, resulting in a number of well-developed typological classifications (Almgren 1897; Heeren \& van Der Feijst 2017). It is with the help of typological classifications such as these, that researchers formulate the chronologies necessary to understand the ever-increasing number of known archaeological sites, and the past societies that left them behind (Lang 2007, $290 \mathrm{ff}$.). But for the copper-alloys, especially for those recovered in the cemeteries of the eastern Baltic, the nature of the raw material choice is less well understood. A better understanding of this is quite important, especially as the region has no raw material source of its own. All the copper-alloy, whether in the form of finished goods, scrap metal, or ingots (perhaps in the form of coins), was imported, at least before it was remelted and put to use in more locally made objects. Therefore, it is of some interest to trace the direction from which this material flowed, in terms of trade routes and the social connections formed through them by distant peoples.

Copper-alloy objects have traditionally been treated in a typological manner, with the raw material typically being referred to as bronze. But this classification is quite misleading, as a new form of alloy was developed and then distributed on an industrial scale across the Roman world during the late 1 st century BC. This new alloy was brass, a mixture of copper and zinc, as opposed to bronze which is made of a mixture of copper and tin (Craddock 1978, 1). Understanding the uptake of this new alloy, in terms of the chronological transition away from bronze and the choice of objects cast in the new brass, tells us something about changes in both craft tradition and the wider society at this time. 


\section{Rome and the Baltic trade route}

To better understand the connection between the peoples of north-eastern Estonia and the Vistula River delta, it is necessary to explore the Vistula's connection to the world much further south. The main source for amber in antiquity was the southeastern coastlines of the Baltic, where the Sambian peninsula and the Vistula delta area have the largest deposits even today (Bliujienè 2011, 5). However, amber is not found further north along the Estonian or Finnish coastlines. In ancient times amber was particularly prized by the Romans, to such an extent that efforts were made to find its source. A number of surviving texts from antiquity mention Baltic amber and the trade routes (the so called 'Amber routes') leading south from the Vistula area. Pliny the Elder, in his Natural History (written around 77 AD), mentions that the main import route south from Germania was through the Roman province of Pannonia, which was bordered from Barbaricum by the River Danube. He also documented the details of a trade mission sent out with the specific task of locating the south-east Baltic coastline and to bring amber back to Rome. This important mission was headed by a senior member of Roman society (an eques Romanus, a member of the Roman equestrian order) during the reign of the Emperor Nero around 60-62 AD (Bliujienè 2011, 58 ff.). It departed from Pannonia and travelled north to the lower Vistula region. Once there it attended several local markets (Commercia), and triumphantly brought back a large quantity of amber that was consumed in a lavish display designed to underscore the power of Imperial Rome. It is clear that this contact strengthened the already well-established relationships between the peoples of the Vistula and the Roman empire, its provinces, and the far northern edge of Barbaricum, and in doing so invigorated the southerly trade via the amber route (ibid., $63 \mathrm{f}$.).

Rome always had some degree of relationship with its northerly neighbours, and this is true of the tribes living in close proximity to Pannonia. The evidence suggests that Roman influence was very much based on social and economic relationships than military ones (Pitts 1989, 58). Tacitus also noted the large number of Roman traders present in the barbarian capital of the powerful Marcomanni tribe, whose lands bordered Pannonia (Tacitus, The Annals, 2, 62). Trade over the border between Rome and the Marcomanni was highly profitable during the early 1st century AD, and a similar situation appears to have been true between traders from the Hermunduri tribe, engaging with the neighbouring Roman province of Raetia (Pitts 1989, 47). Raetia has the only excavated production site of Prussian eye brooches (Voss 2008, 343 f.). It is likely therefore that Roman traders were relatively free to explore the northern Germanic areas far beyond the frontiers in search of new sources of raw materials and new markets for Roman goods.

But another way that personal objects could have moved north is through the movement of people. It is thought that the manpower demands of the Roman Legions and its Auxiliary forces attracted mercenaries from northern Barbaricum (Grane 2011, 102). Some retiring veterans may well have chosen to return to their homelands at the end of their service, taking their 'Roman' personal equipment with 
them (Salo 1968, 129). This hypothesis has also been discussed for eye brooches (Heeren \& van Der Feijst 2017, 76; Roxburgh \& Olli 2019, 226).

\section{Sea contact in the Baltic}

It has been suggested that even in the early Roman period the south-eastern corner of the Baltic Sea acted as a port of trade (Banyte-Rowell et al. 2016, 142), presumably connecting its seagoing communities to market activities taking place there and subsequently connecting to the land and river routes south to the distant Roman provinces. Contact between the pre-Vistula and north-eastern Estonia is also thought to have been via the sea route (Lang 2007, 206). However, no evidence of ancient sailing vessels has yet been found around the Baltic Sea area, so it is thought that this technology was only adopted as late as the pre-Viking Age. Prior to this, sea travel must have been via rowing vessels. The Nydam B ship, found on the Danish Baltic coastline, is the oldest known rowing vessel in northern Europe and dendrochronology has helped date it to the late Roman period (310-320 AD). Experimental tests have concluded that the boat had a maximum speed of 8 knots, but with a minimum "cruising" speed of 3 knots (Bockius \& Grabert 2013, 246). This is approximately a person's walking speed. But with a crew rowing for perhaps 10 hours a day, $55 \mathrm{~km}$ a day could have been achievable. This suggests that it could have taken up to two weeks to travel the distance between the Vistula delta and Estonia's north-eastern coastline. This can also be compared against Wulfstan's longer sail assisted journey from Hedeby (Denmark) to Truso (Vistula delta) in 890893 AD, which took 7 days and nights (Bliujienè 2013, 130).

\section{Roman coins in the eastern Baltic}

Roman sestertii coins are believed to have found their way to Estonia during the 3rd c. AD (Kiudsoo 2012, 293). This date is late in comparison to the finds of sestertii in the lands around the Vistula delta, which were mainly struck in the 2nd and first half of the 3rd century - although a small number of copper-alloy coins dating to the 1st century have also been found there (Bitner-Wróblewska 2010, 4; Zapolska 2011, 1123). Regardless of date the presence of Roman coins in the southeastern Baltic is thought to be associated with exchanges made for amber (Zapolska 2013, 107).

Apparently, Roman coins were not just reserved for transactions within the Roman provinces, they have been found in some quantity across Barbaricum and presumably frequently used in different forms of exchange. As explained by Tacitus, the Germanic tribes did not understand the basics of coin use beyond the frontiers (Tacitus, Germania 5; 26). They regarded coins as metal ingots rather than currency in the regions further away from the Roman economic sphere (Pitts 1989, 57; Bliujienè 2013, 433 ff.). 
Coins, and the heavy copper-alloy sestertii in particular, probably entered the Vistula region as a commodity. It seems that they were primarily intended as raw material to be used in the creation of new local produce, or to be passed on as is, in further exchanges (Bliujienè \& Butkus 2017, 438). Past research into the composition of Roman sestertii suggested that both the weight and compositions of local jewellery coincided with the weight and composition of the coinage - 14-15 $\mathrm{g}$ and 22-25 g for worn sestertii in Lithuania (Bezzenberger 1904, XVIII-XXI; also, for Lithuania see Bliujienė 2013,429). This suggests the systematic use of coins as ingots in local production.

The Roman state controlled the production of sestertii, and the coins produced between the 1 st century $\mathrm{BC}$ and 1 st century AD are predominantly made of brass containing high percentages of zinc (with only a trace of lead or tin). By the third century, however, the zinc content had declined considerably, with a proportional increase in tin, allowing the compositions to be reclassified as gunmetal (a deliberate mixture of copper, zinc, and tin, with or without additional lead) or even bronze (see Dungworth 1996, on chronology of zinc decline in Roman coins, also Caley 1964, table XLI). In Craddock's assessment of early Roman brass use during the 1 st and 2 nd centuries, he suggests that it was usual for the metalworkers to dilute (or top up) pure brass with scrap bronze, as the result was perfectly good for everyday objects. However, coin makers at this time must only have used copper to dilute the brass, hence the presence of only trace quantities of tin. This is also true of Roman military equipment at this time. So, the brass smelters supplied pure tin-free brass ingots to the imperial coiners and legionary workshops, who subsequently diluted it with copper where necessary. Conversely the commercial producers seemed to have mixed brass with scrap bronze (containing tin), probably for economic benefits (Craddock 1978, 13). A confounding factor is that some of the zinc is lost every time a brass object is remelted (Dungworth 1996, 231). So, in each melting event the composition would firstly reduce in zinc, and if local production followed the Roman commercial tradition of mixing in scrap bronze to make up the shortfall, one could expect an increasing amount of tin and lead in the resulting objects.

Past attempts have been made to analyse the compositions of Roman imperial coins found in the Baltic area. Bezzenberger's analyses suggested that the sestertii of the Augustan period (27 BC - 14 AD) contained copper and zinc, but with only traces of tin and lead. But by the 2nd century, the sestertii of Marcus Aurelius (161$180 \mathrm{AD}$ ) and later Emperors contained copper, zinc, tin and lead. An attempt at making a chronology based on the zinc decline in Roman brass coins was made by Caley in order to better identify coins that are badly corroded or worn (Caley 1964, table LXI). His table also demonstrated that high zinc levels $(20 \%+)$ in combination with little or no tin and lead were a common feature of the coinage in the first half of the first century AD. But more importantly this high value is absent in coins after 68AD. Dungworth puts the date even earlier, suggesting that the coins after Gaius (Caligula) - 37-41 AD are below 20\% (Dungworth 1996, 230, fig. 2). A more recent local analysis of Roman sestertii found in Lithuania by Bliujienė in 2013, showed 


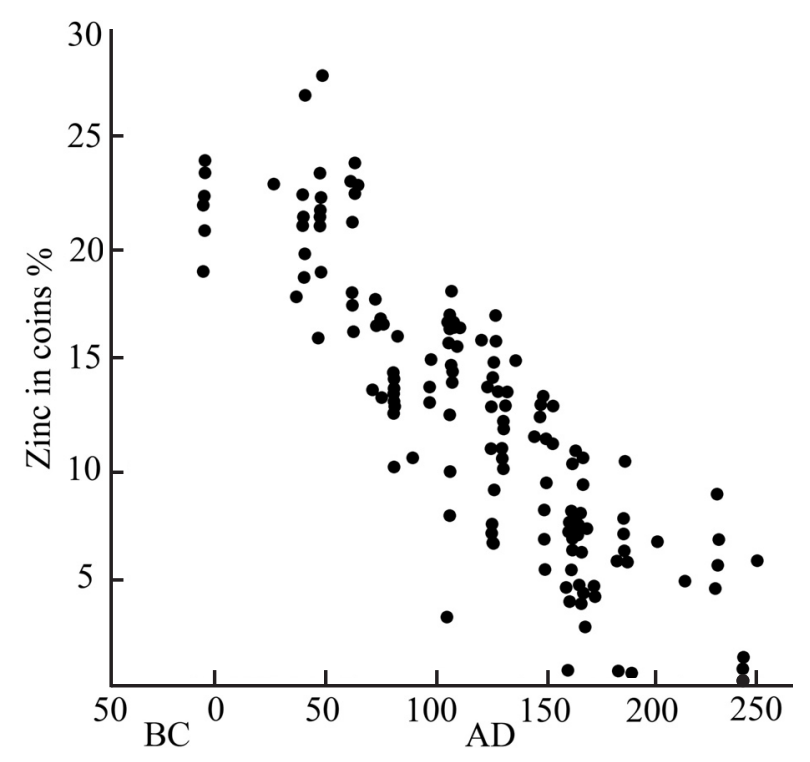

Fig. 1. Zinc content in Roman sestertii coins found in Lithuania (drawn by author, after Bliujiene 2013, fig. 241).

the same trend, that coins with a higher zinc content are absent from around 60AD - see Fig. 1 (after Bliujiene 2013, 363, fig. 241). Importantly, this analysis also showed a correlation between the composition of locally produced objects and the sestertii coins in circulation at the time. In summary the coins with a high zinc content can be reasonably dated from $27 \mathrm{BC}$ to around 50/60 AD. Which in the Estonian chronology would place their production in the late pre-Roman Iron Age.

\section{Chronological changes in Estonian cemetery practices}

The chronology of stone-built cemeteries in Estonia has long roots. There are a variety of types whose origins date from the Bronze Age and the early Pre-Roman Iron Age, of which circular cairn and stone-cist graves are amongst the most frequently found. 'Early' tarand cemeteries deviate from these older circular construction traditions, in that they are formed from a sequence of loosely rectangular enclosures with flat faced outer walls. The earliest of them (normally without grave goods) date back to the beginning of the Pre-Roman Iron Age, but those containing grave goods (copper-alloy items especially) date between the 3rd century BC and the 1st century $\mathrm{AD}$, i.e. the beginning of the Roman Iron Age. This 'early' tarand cemetery form has similarities with those found in other coastal areas around the Baltic Sea. They occur in south-western Finland, the eastern coast of central Sweden, northern Latvia and the Courland peninsula (Latvia), but this is the most southern limit (Lang 2007). 
This 'early' tarand construction gives way to the 'typical' tarand form somewhere in the 1 st century AD, and as mentioned earlier is a change that is used to identify the transition to Estonia's Roman Iron Age (the earliest 'typical' tarand cemeteries in Latvia are also dated to the 1st century; Ciglis 2013, 115). They are larger in size than the 'early' type, probably to accommodate an increasingly communal burial practice, dominated by cremations. They also appear to be constructed in a much more uniform (standardised) manner, with well laid out adjoining rectangular enclosures, frequently arranged on an east-west axis. The earliest evidence for this transition appears along the coastal area of north-eastern Estonia, and is thought to have been completed by the 2 nd century AD. But the practice started spreading outwards into the rest of Estonia during the middle of the 2nd century AD.

One of the most important tarand cemetery complexes to be excavated was at Jäbara (Lüganuse parish, Ida-Viru county, north-east Estonia). It was systematically excavated in the 1920s and 1930s by Schmiedehelm who located a transitional stage in the part of the cemetery labelled Jäbara C (Schmiedehelm 1955, 61-110). This paper focuses on this transitional area of the Jäbara site.

\section{The excavation at Jäbara}

The cemetery complex at Jäbara, is situated on the north-eastern Estonian coastline, about $140 \mathrm{~km}$ east of Tallinn and about $780 \mathrm{~km}$ north-east of Kaliningrad and the Vistula River delta (see Fig. 2). The cemetery (known locally as Kärrismäe or Kärrismägi) is located beside the road that connects the villages of Jäbara and Moldova. It sits at the junction of a smaller road that leads down through the high

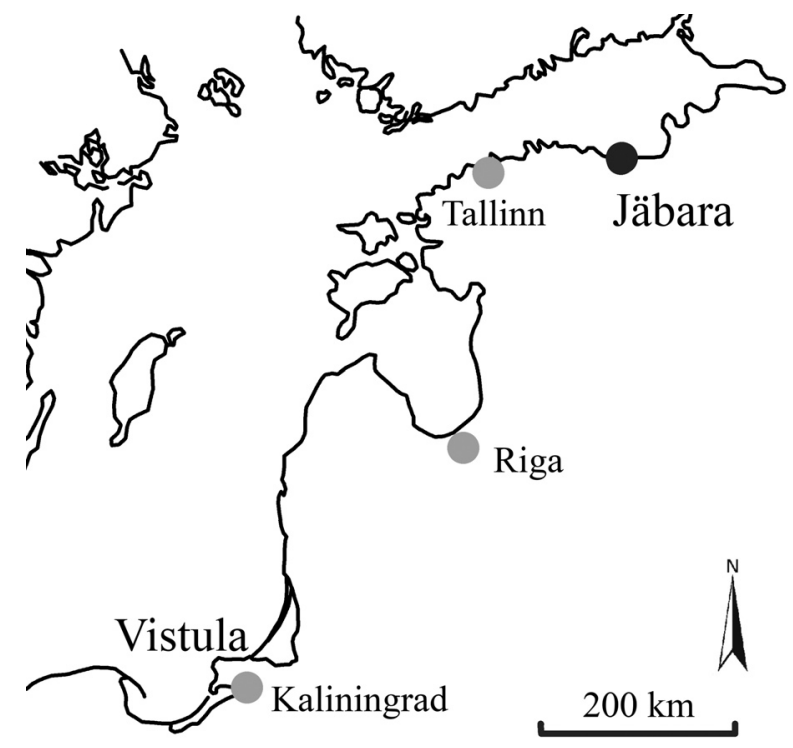

Fig. 2. Jäbara in relation to the Vistula delta. 
limestone cliffs to the beach, a little over $1 \mathrm{~km}$ away (see Fig. 3 upper). It can be seen as a low hill in the fields running immediately south-west from the junction. This cemetery hill stretches about $0.5 \mathrm{~km}$ into the fields and is up to $1.3 \mathrm{~m}$ in height in places (Schmiedehelm 1925, 1). It is mainly comprised of a mixture of soil and
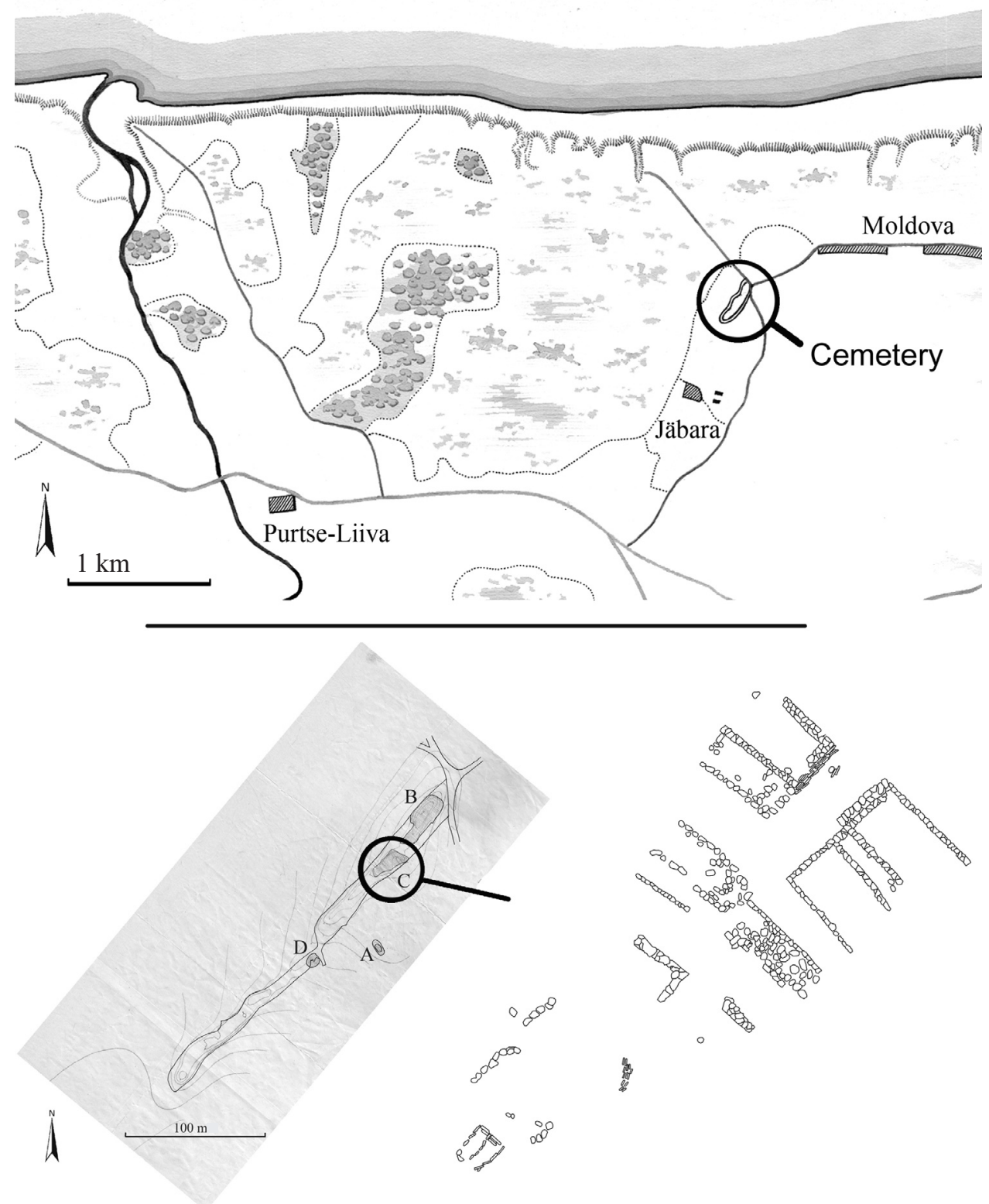

Fig. 3. Upper - Jäbara tarand cemetery, location plan (drawn by author, after Schmiedehelm 1927, unpublished location plan); lower - location of Jäbara A, B, C, D, with detailed excavation plan of cemetery C complex (drawn by author, after Schmiedehelm 1955, fig. 3 \& Map IV). 
limestone fragments, but over the years a lot of additional limestone boulders have been dragged onto it by farmers clearing the surrounding fields. When Schmiedehelm arrived in 1925 she noted five places where robbing or previous explorations had taken place in the past. The robbing of or otherwise disturbing of graves was widespread from antiquity to the present day, especially for more richly furnished inhumation burials (van Haperen 2010; Bitner-Wróblewska \& Rzeszotarska-Nowakiewicz 2016, 278).

The excavation of Jäbara C was undertaken in the summer of 1927 (Schmiedehelm 1927; 1955, 61-110). Two stone cist graves possibly dating to the late pre-Roman Iron Age were found at the south-western end of the excavation. Conversely, a number of 'typical' tarand enclosures dating to the Roman Iron Age dominated the area at the opposite north-eastern end. However, the "transitional" area in between these two features is less defined.

The rows of stone immediately to the north-east of the cist graves appear to be slightly curved, which Schmiedehelm hinted at being the remains of stone circles (Schmiedehelm 1927, 2). If so this area of the complex would associate with the pre-Roman Iron Age. Lang associates this disturbed transition area with the Kurevere type of 'early' tarand grave, which are characterised by irregular, somewhat carelessly built sub-rectangular stone enclosures, alongside or attached to much older circular cist or cairn graves. But this addition also suggests a late preRoman date (Lang 2007, 170, fig. 103).

The excavation produced an inventory list of 225 finds which can be divided up by material as follows; 62 iron objects, 27 groups of pottery fragments, 9 of bone, 2 flints, 2 glass beads, and 123 copper-alloy objects. Four groups of copper alloy objects were subsequently selected for closer scrutiny for their potential to better date the transition phases of the cemetery (see Fig. 4 and pXRF methodology section below).
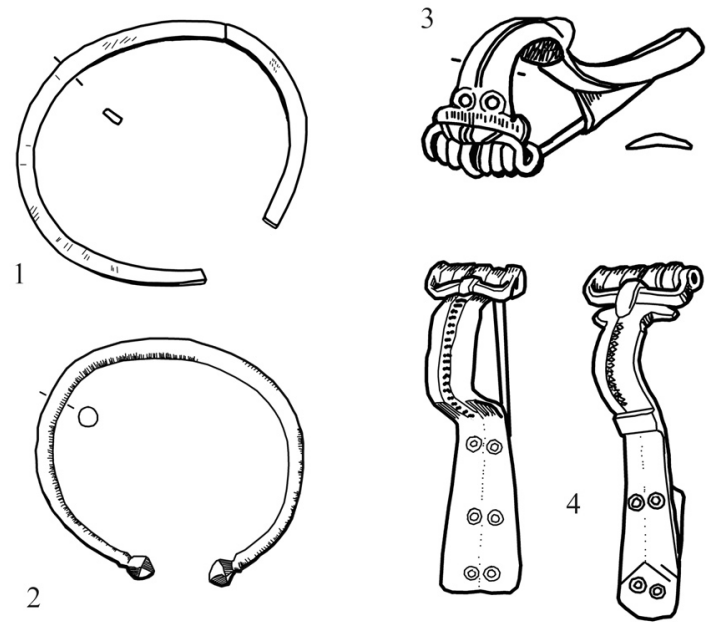

Fig. 4. Artefact types from Jäbara C. 1 - serial bracelet (AI 2617: 34), 2 - end-knob bracelet (AI 2617: 112), 3 - main series eye brooch (AI 2617: 201), 4 - Prussian series eye brooches (AI 2617: 113, A60 type; AI 2617: 98, A61 type). Drawn by author, after Schmiedehelm 1955, figs 12: 1; 13: 5, 6, 10; 14: 8. 


\section{History of pXRF}

The composition of ancient copper-alloy artefacts has been attracting attention for over 250 years. One of the earliest recorded pioneers, Prof. Friedemann Göbel conducted his research at Dorpat University (present day Tartu), Estonia in the early 19th century (Göbel 1842). He was one of the first to recognise the value of archaeometallurgical analysis in relation to understanding past societies.

It was only in the 1950s, however, that research in this area really took off. This was due to the invention of new X-ray technologies that developed in the years after the WW II. This new technology gave rise to a number of new laboratory-based techniques for the study of archaeological artefacts, including X-ray fluorescent spectrometry (XRF). Over the years this technique has contributed considerably to our understanding of the way past craftsmen worked with copper-alloy (Bayley \& Butcher 2004; Martinón-Torres et al. 2012; Olli \& Roxburgh 2018, and many others). This device was originally a very bulky, immobile piece of laboratory equipment, but thanks to advances in miniaturisation has become increasingly portable. The current range of models are easily packed into a carry case for transportation to archives or archaeological excavations, a portable test bench is also usually provided for a more stable operating environment (for more details see Gigante et al. 2005; Potts \& West 2008; Shackley 2011). There are still a number of other laboratory-based methods available, but these require the destructive removal of a sample from the object, usually by drilling or scraping. This level of damage is quite opposed by modern conservation practices. However, the results from these destructive analyses have the potential to be interpreted in a quantitative way. But these portable, easy to operate XRF devices can be employed in a nondestructive manner by taking surface measurements (Tate 1986; Lutz \& Pernicka 1995; Bayley \& Butcher 2004; Roxburgh et al. 2016; 2018). This requires a different approach by asking different qualitative questions of the data. This is because the $\mathrm{X}$-rays from a pXRF device can only penetrate a fraction of a millimetre at most into the surface of a copper-alloy artefact, which is always the patina or the altered surface directly below it. The implication is that these surface measurements are massively altered by the corrosion process. The main changes to the corroded surface are decuprification (which is the leeching of copper from the outer surface) then similarly but to a lesser extent dezincification - the leeching of zinc (Robbiola et al. 1998, 2108; Chiavari et al. 2007). But armed with this knowledge, modern pXRF machines are useful and capable of addressing certain archaeological questions.

\section{Material}

The artefacts excavated from the Jäbara tarand cemetery and presented in this paper, are housed in the archaeological research collection at Tallinn University. Eye brooches - eye brooches can be divided into three series; 1) main: 2) Prussian 
3) Estonian (Almgren 1897, 21 ff.; Roxburgh \& Olli 2019; Bliujienè et al. 2020). But for the purpose of this paper, we focus on the main and Prussian series due to their non-local nature. The Estonian series are later in date and dealt with elsewhere (see Roxburgh \& Olli 2019, 220; Fig. 5). A typical identifying feature of the eye brooches of the main series is that they are a one-piece construction, meaning that their spring and pin emanate directly from the head of the brooch (whilst the spring and pin are made separately for the Estonian series, then subsequently attached). These brooches have 'open' holes (eyes) on their head but can sometimes be "closed" and marked with dimples instead. The main series are the earliest eye brooches found in Estonia (solely distributed along the north-eastern coast) and are believed to date from 50 AD onwards (Lang 2007, 206; Roxburgh \& Olli 2019, 211). This series has also been dated to between 20-80 AD for the Vistula region (Nowakowski 1998, 107), which compares reasonably to the date from finds in the Roman provinces - 5-70 AD (Heeren \& van Der Feijst 2017, 73). They are widely
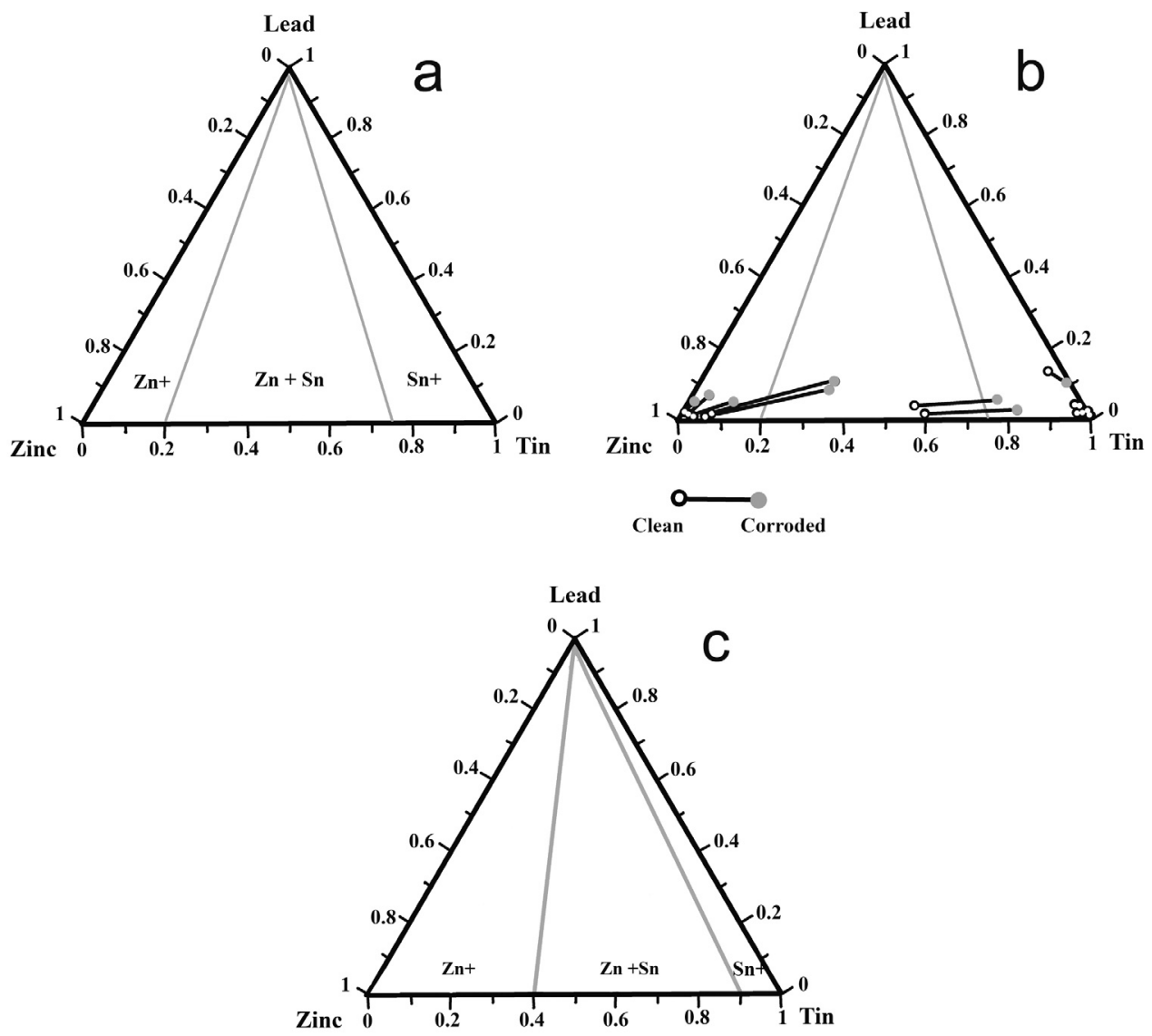

Fig. 5. a - classification scheme after Roxburgh et al. (2018, 8, fig. 1), b - deviation from corrosion, after Roxburgh et al. (2018, 9, fig. 2), c - interpretation of deviation based on Fig. 5 b (Zn+= Brass, $\mathrm{Zn}+\mathrm{Sn}=$ Gunmetal, $\mathrm{Sn}+=$ Bronze). 
distributed through Barbaricum, from the Danube basin to the River Rhine. They are found in significant numbers in Poland (for example, in the burial grounds of the Lower Vistula; see Anger 1890, table 12: 1, 2; Almgren 1897, 176 ff.), where they are also dated to the 1 st century and are common in the Kaliningrad region, to the east, and are also present in Lithuania, where they are thought to date from around $50 \mathrm{AD}$ (Bliujienè et al. 2020). They are also found in Scandinavia and Finland. Because of the coastal nature of the find locations in Estonia, the opinion has long been expressed that these brooches arrived by sea, which suggests a degree of communication between the north-eastern coast and the Vistula delta.

Three specimens of the main series were found in Jäbara C (AI 2617: 95, 201, 208). Brooch AI 2617: 201 is an Almgren (1897), 49, and the earliest typologically speaking (Fig. 4: 3). It has "open" eyes and a transverse ridge on the bow, along with other early features. Brooches AI 2617: 95 and 208 with "closed" eyes and low crests are of a later date (Almgren 1897, 50; Schmiedehelm 1955, 66, 71, fig. 13: 4). According to Almgren these brooch types are common to the Roman Provinces and northern Europe. Jäbara $\mathrm{C}$ also produced five eye brooches of the Prussian series from Almgren 1897, 57, 59, 61 (Fig. 4: 4), which are thought to date to the 1 st and 2 nd century (Roxburgh \& Olli 2019,216). The characteristic features of these brooches are the presence of a spring made of rectangular wire, an absence of 'eyes' on the head and the presence of 'ring and dot' stamped decorations (resembling eyes) on a relatively wide flat foot. Compared to the other eye series brooches, (distinguished by their careful finish, and imaginative detail), the Prussian brooches are conspicuous by their monotony of decoration and careless (clumsy) production. Schmiedehelm $(1955,65)$ suggested that they were made in one or more production centers and that they probably spread overland to the territories of Lithuania and Latvia from the Vistula delta area but travelled by sea to north-eastern Estonia, the same way as the brooches of the main series.

The search for a Prussian production site for these brooches was undertaken by B. A. Rybakov in 1948, using a detailed methodological analysis of their construction methods. The aim was to identify the distribution areas that received the finished goods from ancient Russian workshops (1948, 29 f.).

However, items of jewellery are light and highly portable, and more recent archaeological work has uncovered a large production site for these Prussian types (Almgren 1897, 57, 59, 60) in the Roman province of Raetia, now Augsburg, Bavaria by H.-U. Voss, who first posed the question that they might be traded north from the provinces into the amber producing areas $(2008,343 \mathrm{f}$.). This is quite some distance from the Vistula, but conversely it is situated in close proximity to the southern (Roman) end of the 'Amber Route'. These brooches therefore were most likely being mass produced for export, or at the very least issued en masse to Germanic-Roman soldiers who took them home after the end of their service (Heeren \& van der Feijst 2017, 76). Either way the notion that these brooches are local Vistula products is no longer viable, supporting the idea that a great many other copper-alloy objects found in the Vistula area were travelling north along this 
route as well. For more details about the 'Prussian' series A57-61 in the European Barbaricum see U. Pfeiffer-Frohnert (1998).

End-knob bracelets - another object characteristic of the eastern part of the Jäbara C burial ground, are the bracelets with knobs on the ends of which 9 examples were found there (Fig. 4: 2). They usually have a circular cross-section and taper somewhat towards the ends. The knobs on the ends of the bracelet can also be rather small and poorly formed. At the time of this excavation, two more examples had been found outside of north-eastern Estonia, occurring in the enclosures of stone burial grounds, with inventories dating to the 2nd century AD (Moora 1938, 388 ff.). One bracelet of this type was found in the stone burial grounds of northern Latvia, but at the time of Schmiedehelm's research they had not been found in Lithuania. These bracelets found across Estonia and Latvia, have the same distribution area as the main series eye brooches. They have now also been found in relatively small numbers in the Kaliningrad Region, to the south-west, but are very common in the burial grounds close to the lower Vistula (Blume 1912, $60 \mathrm{f}$; Michelbertas 1997). Schmiedehelm suggested that these bracelets spread to northeastern Estonia by the same sea route as the eye brooches of the main and Prussian series. The bracelets found at Jäbara are rather carelessly made and in that sense also match the quality of the Prussian eye brooches. The knobs for example often do not have a definite geometric shape. Schmiedehelm suggested that these Jäbara bracelets were a late version of an earlier type, dating from the 1 st century. In the earlier bracelets, the ends of the bar are sometimes clearly profiled, and the knobs are spherical with more care being taken in the overall finish, compared for example, to the bracelets from the stone graves in Triigi (Hausmann 1896, table IV: 7, 8). Lang also agreed that they spread by sea throughout north-east Estonia with the main series eye fibulae, from the Vistula (Lang 2007, 213). But this bracelet is not unique to the eastern Baltic. It is quite common for the north-western Roman provinces including the Dutch River areas (Lower Rhine), they are mainly thought to have an early Roman or 1 st century date (Riha 1990, 56, type 3.11; Sas \& Thoen 2002, 172 ff., cat. 85-89, 96; Heeren 2009, 143 ff.).

An end-knob bracelet (AI 2013: 7) recovered from almost identical conditions as Jäbara was available for analysis from another location. It was found by chance amongst a pile of stones (probably an undiscovered tarand grave) near the village of Avispää, Väike-Maarja parish, north-eastern Estonia. The find year is unknown, but it was deposited in the archaeology archive at Tartu University in 1896. This is arguably one of the better produced early versions, in line with Schmiedehelm's comments about the Jäbara finds (mentioned above).

Serial bracelets - these bracelets with a rectangular cross-section were worn in multiple groups (see Fig. 4: 1). Jäbara C produced 11 in total, but some of them were in a fragmented condition (Schmiedehelm 1955, 63, 67, fig. 12: 1, 5). Schmiedehelm suggested that these bracelets share some of the same characteristics as those with faceted knobs (see below) in that both types are small in diameter and very thin. These bracelets are found across the northern and south-eastern part of Estonia and the tarand cemetery areas of Latvia (Moora 1938, 401, Appendix 2). 
They first appear during the Pre-Roman Iron Age but are most frequently found in graves dating to the 1 st or 2 nd centuries; however, their size becomes noticeably larger by the 2nd century (Lang 2007, 213, fig. 134: 2). A few of these bracelets have also been found in the 'early' tarand area of eastern central Sweden (Bennet 1975,59 ff.). These serial bracelets can be considered to be a Baltic form of personal ornament, relating to the people buried in tarand cemeteries.

\section{Method - pXRF}

Qualitative (non-destructive) approach - the pXRF study was conducted onsite at the university archive in Tallinn, using a Bruker tracer IIIsd, handheld, pXRF device. Subsequently the device was mounted to its portable test bench throughout the datagathering phase. The device was fitted with the yellow filter (position 1) - dry air atmosphere - as recommended for the high mass elements found in copper-alloys and set to $40 \mathrm{kev}-10 \mu \mathrm{m}$. After trial testing at differing time intervals, the signal was found to be stable at 60 seconds. These settings were subsequently maintained throughout the exercise. The output was saved in PDZ file format, which allowed the spectra to be individually checked for inconsistencies with the manufacturers dedicated S1PXRF software. To convert the data into quantitative chemical weights (in \%), a manufacturer supplied copper-alloy calibration (Cu1) was used. The elements measured through this calibration were $\mathrm{Mn}, \mathrm{Fe}, \mathrm{Co}, \mathrm{Ni}, \mathrm{Cu}, \mathrm{Zn}, \mathrm{As}, \mathrm{Pb}, \mathrm{Bi}$, $\mathrm{Zr}, \mathrm{Nb}, \mathrm{Ag}, \mathrm{Sn}, \mathrm{Sb}$. One measurement per artefact was undertaken, taking care to consistently present as much of the object as possible to face the XRF emission aperture. An external normalisation of the completed dataset was then undertaken in Microsoft Excel ${ }^{\mathrm{TM}}$ to correct for contamination from soil and other light element residues. The alloying elements $\mathrm{Cu}, \mathrm{Sn}, \mathrm{Zn}, \mathrm{Pb}$ were then normalised on a light element free basis. To aid intermachine comparison and measurement repeatability the calibration of the Bruker analyser was compared against a Niton XL 3t GOLDD XRF analyser, using a shared set of copper-alloy samples. The Niton analyser (from the Cultural Heritage Agency of the Netherlands) had in turn been checked against the CHARM heritage alloys reference set, the details of which are published elsewhere (Heginbotham et al. 2015; Roxburgh et al. 2016, 411). A comparison of the measurements from both machines are presented in Appendix 2. There is a small variation between the two machines, but it is not large enough to hinder the analysis conducted here. The measurements were taken on the uncleaned corroded surfaces in line with previous studies.

Classification - the measurements were subject to an object-by-object review of the elemental values presented in Appendix 1, (a necessary check for unusual outliers), then classified in line with Fig. 5 (c). The results were presented in ternary diagrams in Fig. 7.

Quantitative (destructive) approach on the Avispää bracelet - after weighing, the pXRF method was exactly as above, except that a first measurement was taken from the corroded area selected for removal. Then this area of outer corrosion was 
removed by a new jewellery file, down to clean fresh internal metal (past any small blemishes or remaining patches of altered outer surface). Subsequently a second pXRF measurement was taken on the clean fresh internal surface. This second measurement was then classified using Fig. 5. (a) so that comparisons could take place.

\section{Results}

The results of the $\mathrm{pXRF}$ measurements for Jäbara $\mathrm{C}$ are presented diagramatically in Figs 6 and 7. They are followed by the quantitative measurements on the end knob bracelet from Avispää.
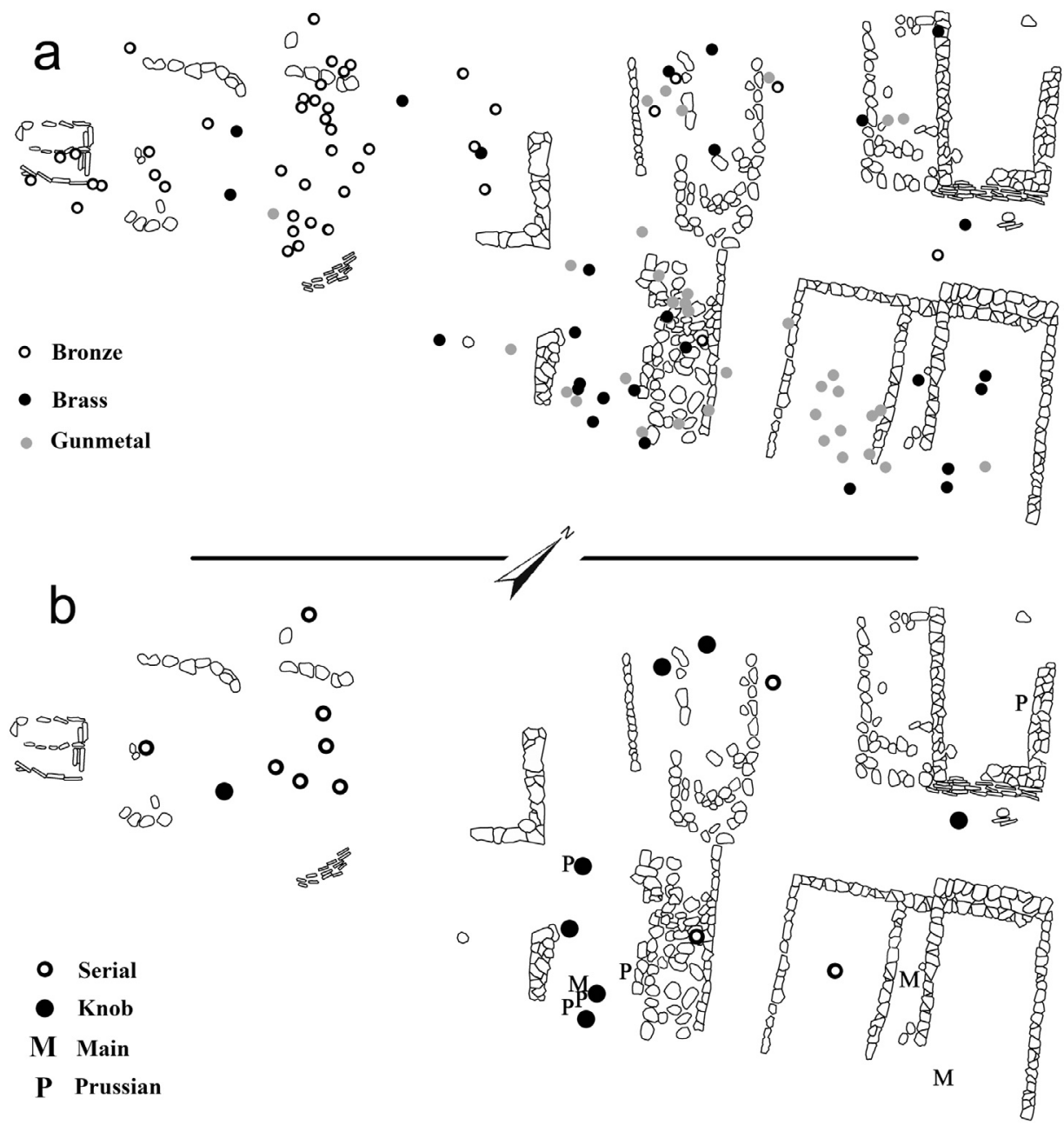

Fig. 6. Plot of all copper-alloys in Jäbara C (a); plot of serial bracelets, end-knob bracelets, eye brooches of the main series, and Prussian series (b). 

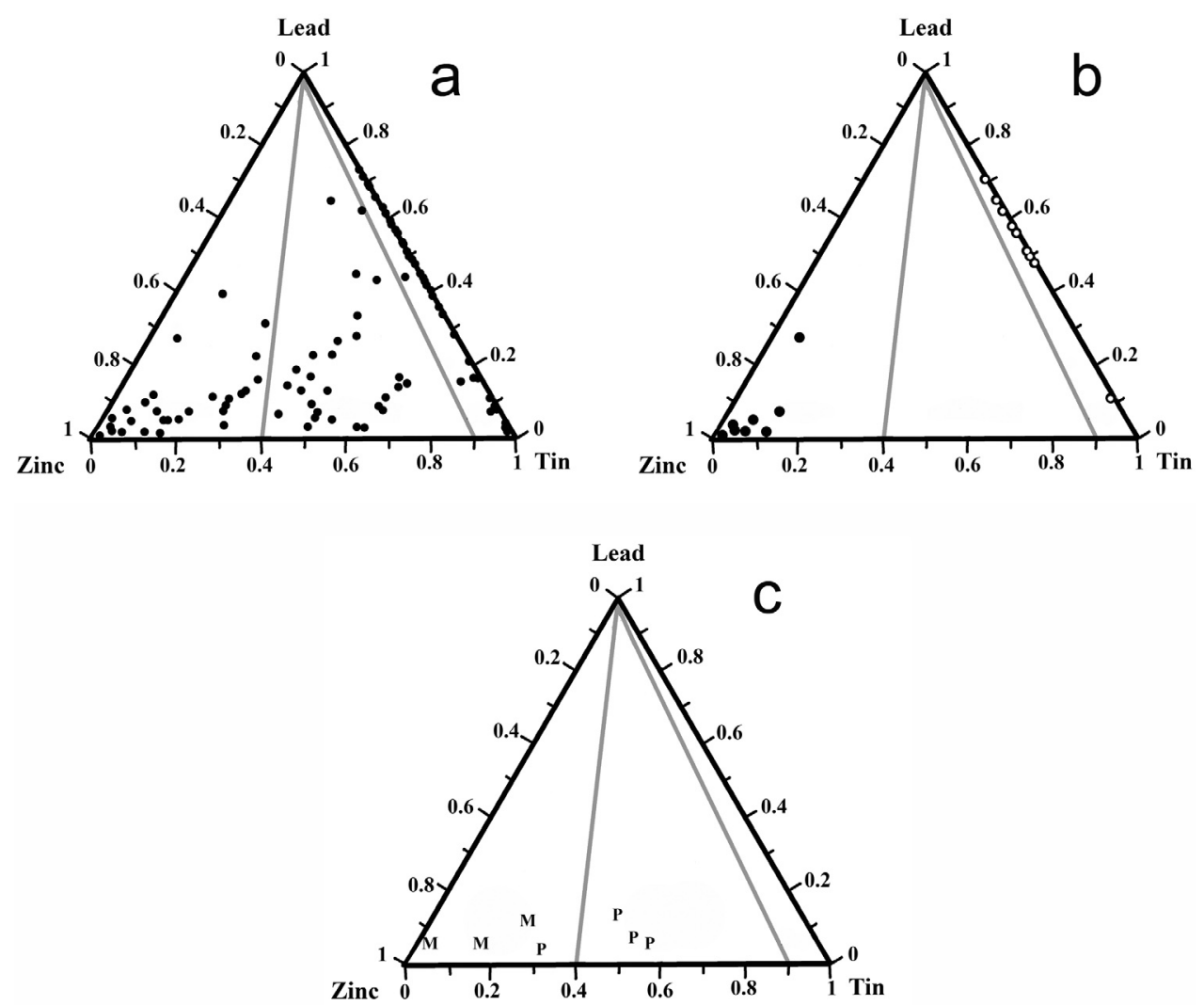

Fig. 7. Jäbara C: ternary plot of all objects (a), plot of end-knob (black dots) and serial bracelets (b), main series (M), and Prussian series (P) eye brooches (c).

Destructive test - end-knob bracelet (AI 2013: 7)

Weight $-25.4 \mathrm{~g}$

Corroded results

$\begin{array}{llll}\mathrm{Cu} & \mathrm{Zn} & \mathrm{Pb} & \mathrm{Sn} \\ 93.9 & 3.5 & 1.1 & 1.5\end{array}$

Cleaned results $\mathrm{Cu}$

$\begin{array}{llll}\mathrm{Cu} & \mathrm{Zn} & \mathrm{Pb} & \mathrm{Sn} \\ 77.6 & 21.5 & 0.5 & 0.5\end{array}$

Figure 6 plots the find location of the artefacts across the cemetery. In the first section (a), they are differentiated between bronze, brass and gunmetal ('white', black and grey dots respectively). In the second section (b), only the finds from the four artefact groups are present. The serial bracelets, knob end bracelets, main and Prussian series eye brooches are marked by 'white' and black dots, then the letters $\mathrm{M}$ and $\mathrm{P}$ respectively. 
Figure 7 plots all the pXRF measurements into three ternary diagrams. Diagram (a) plots the measurements from all the objects in the cemetery (see also Appendix 1). Diagram (b) only plots the measurements for the end knob bracelets and serial bracelets (black and 'white' dots respectively). The last diagram (c) only plots the positions of the main and Prussian series eye brooches, $\mathrm{M}$ and $\mathrm{P}$ respectively.

The measurements for the Avispää bracelet include its weight, then its corroded and clean normalised values for copper, zinc, lead and tin.

\section{Discussion}

The first observation in Fig. 6 (a) is that there is a clear division between the objects made from bronze and the objects made from brass and gunmetal. Specifically, $88 \%$ of the bronze objects were located around the pre-Roman Iron Age features (38 of 43), namely the cist burial and 'early' tarand area (south-west side of the plan). If this area is from the pre-Roman period, then it should only contain bronze, as zinc in the form of Roman brass had not yet entered circulation, or at least not yet arrived in funeral contexts. The brasses and gunmetals in contrast locate to the north-east side of the plan. This mainly relates to the area containing the 'typical' tarand cemetery, but with an overlap into the potential 'early' tarand area. Therefore $82 \%$ of the objects classified as brass were found here (23 of 28). For the remaining objects assigned to the mixed gunmetal classification, the association with the later area of the cemetery is even stronger. Here $94 \%$ of the gunmetal objects are on the north-east side of the plan (33 of 35). There is no clear divide between the brass and gunmetal areas however, they are intermixed. The transition from a brass dominant period to a gunmetal dominant period is not evident. The reasons for this could include intermittent influxes of different materials (fresh brass or bronze) as well as variations in the intensity of recycling practices, or the speed of the metal trade, but these kinds of events are not easily recognisable, especially because of the large amount of disturbance around the 'early' tarand area and the length of time the cemetery was in use. Clues to this disturbance might be seen in the locations of some of the outliers, in particular the artefact categories chosen for closer analysis.

The eye brooches - the alloy classifications for both main series and Prussian series conform to the alloys published in Roxburgh \& Olli 2019. The earlier main series brooches conform to their 1 st century origin by being made from brass. The Prussian series, taken as a group generally conforms to their later 2 nd century date, having a higher amount of tin in their composition, which is comparable to the Estonian series as well. That said, there is no obvious spatial divide in the find locations in Fig. 6 (b). In fact, a main series brooch is situated in very close proximity to a number of the Prussian series brooches. This could be because this area of the cemetery was in use throughout both centuries, allowing both to be deposited close to each other but perhaps many decades apart. Alternatively, the brooches could 
have been disturbed by past robbing events as people digging there could have done so for reasons quite unrelated to the presence of these copper alloy objects, which could have been discarded along with the stones and soil.

The serial bracelets - as mentioned earlier these objects were thought to have been worn on the arm in groups. They were all produced in bronze, which implies that they were manufactured before brass arrived in the region, or at least that local craftworkers maintained a separate bronze making tradition, during the time that brass objects began to circulate. The majority of the bracelets conform to the preRoman burial areas on the left of the plan. But there are three outliers from the later Roman period in the north-east section (Fig. 6, b). If these outliers associated with the Roman period, then it might be expected that they would have contained some zinc, if only through the local recycling of scrap items. They do not, their composition matches those from the pre-Roman period. Furthermore, these are singular finds, suggesting that they have become separated from their serial groups. One find location in particular is interesting. Bracelet AI 2617: 151 was located on top of the pile of stones (see stone pile in Fig. 6, b). However, a number of objects in brass and gunmetal were found amongst the stones underneath it. This suggests that the bracelet has moved. It could also be suggested that stones were being removed from the 'earlier' areas of the cemetery, perhaps for reuse in the later 'typical' tarand area. Alternatively, the stone pile could be related to the robbing of objects from the 'early' tarand area, in which case a number of the brass and gunmetal objects could have been shifted to the right, perhaps in the dumped material. Another option is that these were heirloom objects that were buried perhaps centuries after they were made, but if that was a common practice you might expect the whole cemetery to be comingled with objects of different periods, which is not the case.

The end-knob bracelets - these bracelets were all made in brass, but with a consistently low amount of tin in the measurements (between 0.2 and $1.3 \%$ ). As these are measurements on the corroded outer surface you would expect tin enrichment to have taken place as zinc is leeched from the surface. Even though it is not possible to determine more quantitative data without destructive cleaning, it strongly suggests that these items were made of a very pure brass, hence a lack of tin in the corroded measurements. But without having a qualitative measure of the percentage of zinc to copper, only a late $1 \mathrm{st} \mathrm{c}$. BC to a $1 \mathrm{st} \mathrm{c}$. AD date can be proposed, based on the sestertii coin data mentioned above. Most of these bracelets ( 6 of 8 , or $75 \%$ ) are located in the later but less defined transition area. This area is just south-west of the more uniformly constructed 'typical' tarand enclosures and associates more with the more disturbed 'early' tarand area. Three of these bracelets are in close proximity to eye brooches and therefore could be related to them. Of the two outliers, the one found on the pre-Roman left of the plan could very well have been the result of disturbance, but if not could be evidence of a very early placement of a brass object into the cemetery. This is because of its close proximity to pre-Roman bronzes. Equally the stray bracelet to the far right on the plan could be from a disturbance, but equally could be from a later deposit. The circulation date for this 
group in the Roman provinces is again the late 1 st c. BC to 1 st c. AD. As suggested by earlier scholars, this imported bracelet group was in circulation in Estonia at the same time as the earliest eye brooches. But the composition suggests that it has the potential to be earlier as well.

Although it is obvious that disturbance has taken place in the past, it is clear from the way the alloys group on the plan that the objects generally conform to the chronology of the cemetery structures, which in turn match the general trend in compositional change for this era.

The quantitative (destructive) sample - was taken from the Avispää bracelet. The alloy mixture corresponds to Caley's sestertii coin group IV $-23 \mathrm{BC}$ to $54 \mathrm{AD}$. Its weight also corresponds to the weight of a single sestertius, perhaps indicating that one coin was used in a single casting event, or at least there is a relationship between the two objects. This date is also supported by Dungworth - the emperors whose coins match this percentage of zinc are Augustus - 27 BC-14 AD and Gaius (Caligula) - 37-41 AD. The compositional graph of the sestertii found in Lithuania (Fig. 1), also gives a cut-off date of around 60 AD. As mentioned earlier, the amount of zinc reduces each time a melting event takes place. Therefore, a later production date seems implausible, as local production would likely have used contemporary coins (or recently traded scrap). Production from coins of the 2 nd or 3rd century contain much lower zinc and much higher tin levels. As it was a common practice in the Roman commercial workshops to add scrap bronze whilst casting (introducing tin into the mixture), it is likely that workshops in northern Barbaricum did the same. Only Roman state production is thought to have controlled its composition through introducing fresh copper rather than scrap. As seen in the coinage and military equipment of the time.

Schmiedehelm's observation that the end-knob bracelets at Jäbara are clumsy in their construction (compared to earlier ones), matches the clumsy construction of the Prussian series eye brooches. This could place them in the 2 nd century, but without destructive testing to measure zinc levels this cannot be explored further. However, a similar manufacturing date and route can be suggested. As mentioned earlier, a manufacturing site for Prussian brooches has been found in the Roman provinces, close to the southern starting point of the amber route. It is likely therefore that the original workshops were located there. This is also supported by the fact that a large number of these bracelets are also found in the northern Roman provinces. If Schmiedehelm's earlier (well-made) end-knob bracelets match the earlier (well-made) main series brooches, the most likely scenario is that both items were produced for export (for trade into Barbaricum), or for use by GermanicRoman soldiers serving in the army (who presumably took the bracelets back north when their time was over). This hypothesis also matches the notion of Roman state production, as this would also include the output from the legionary workshops stationed along the frontier. Date-wise the compositional analysis best places this bracelet in the first half of the 1st century, which is the late Pre-Roman Iron Age in Estonia, but it is a good match for the circulation period for the main series brooches in Barbaricum. 
This suggests that the people living in the agricultural area of north-eastern Estonia were at least receiving copper-alloy objects as trade items from the Vistula delta. Some of these items, such as end-knob bracelets, are likely to have originally entered the Vistula region as trade items for amber, then travelled north to Estonia in further exchanges. With the travel time by sea being only a matter of weeks it allows the possibility of seasonal trade expeditions taking place, perhaps amongst other things an exchange of agricultural surplus for copper-alloy.

\section{Conclusions}

The application of this pXRF approach has contributed significantly to the debate surrounding the transition from the pre-Roman to Roman Iron Age in north-eastern Estonia. The qualitative approach for studying corroded copper-alloy objects revealed strong correlations between alloy classification and find location in a multiperiod tarand cemetery complex. The results shed light on the chronological development of the cemetery and further explored the ability of pXRF to gain meaningful data from corroded copper-alloy objects.

Furthermore, the quantitative analysis of a single bracelet, together with the combined qualitative results from a larger group has added to the debate about the nature of long-distance contact between the people of north-eastern Estonia, the southern Baltic and the distant Roman frontier. It also raises the likelihood that the people of north-eastern Estonia were placing Roman produced items into their cemeteries in the decades before the traditionally accepted start of the Roman Iron Age. A new assessment for the beginning of the Roman Iron Age is called for, one that aligns both end-knob bracelets and main series brooches with the early decades of the 1st century AD.

\section{Acknowledgements}

Thanks go to Prof. Heiki Valk, Centre for archaeological research \& infrastructure (University of Tartu) for approving the destructive analysis of the end-knob bracelet from Avispää. Also, to Dr Ülle Tamla for her help in accessing the Jäbara artefacts at the Archaeological research collection (Tallinn University). The author of this publication was supported by the Estonian Research Council, Mobilitas Plus grant. The publication costs of this article were covered by the Estonian Academy of Sciences, the Institute of History and Archaeology at the University of Tartu, and the Institute of History, Archaeology and Art History of Tallinn University 
文

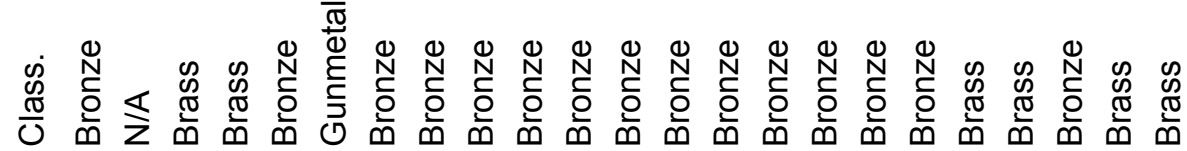

๘

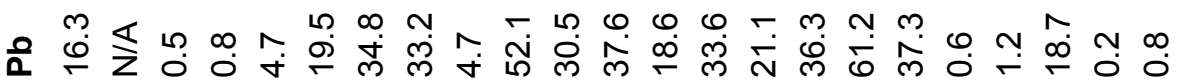

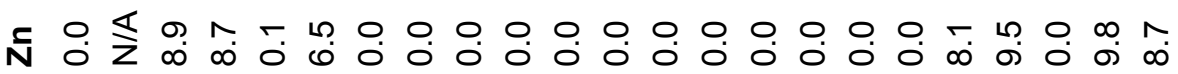

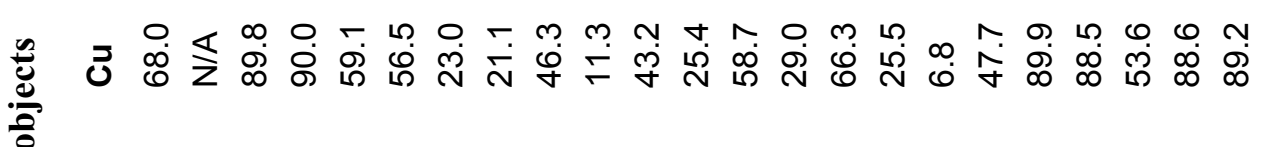

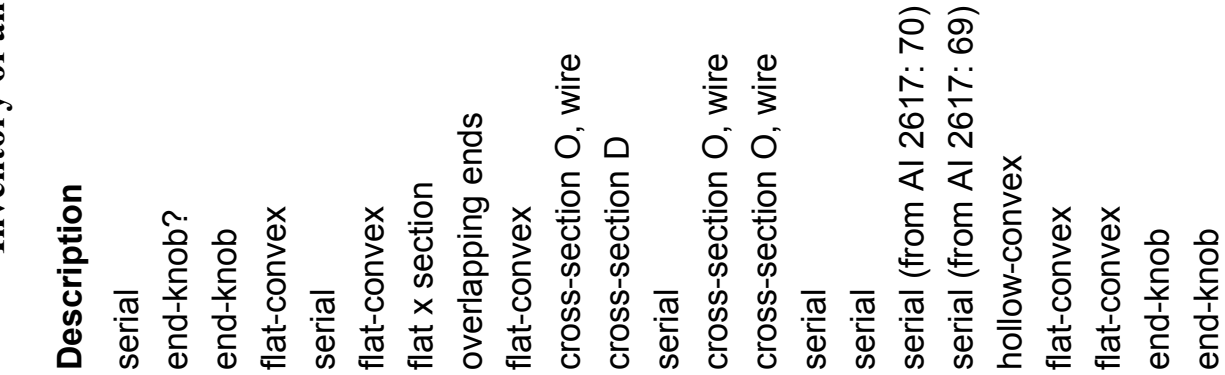

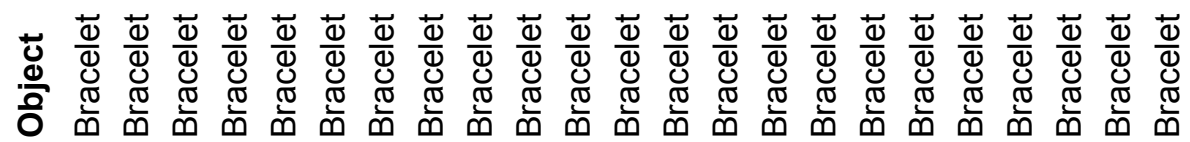

స

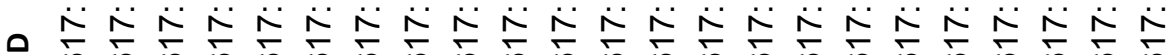

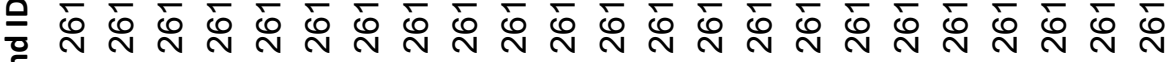

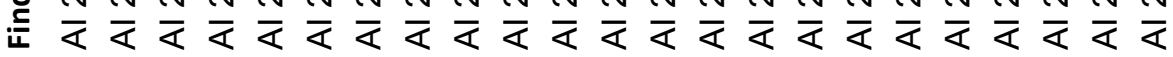




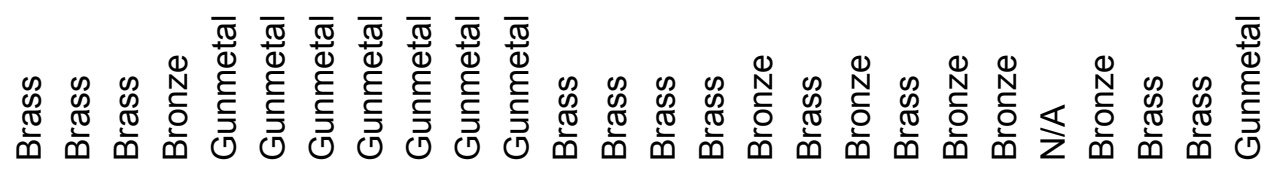

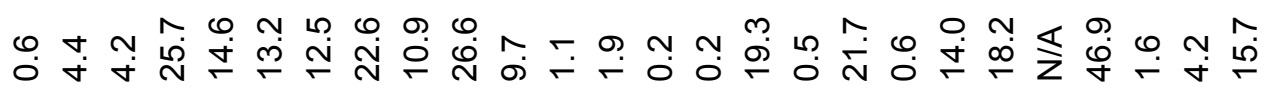

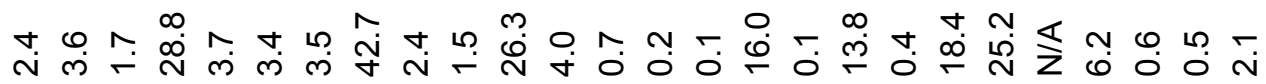

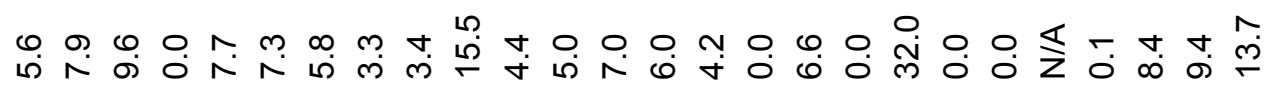

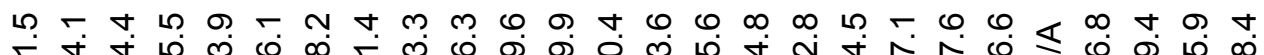

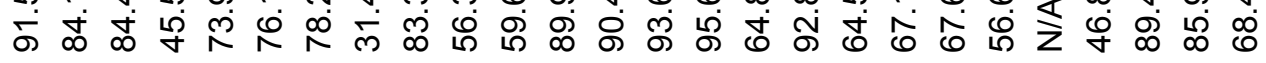

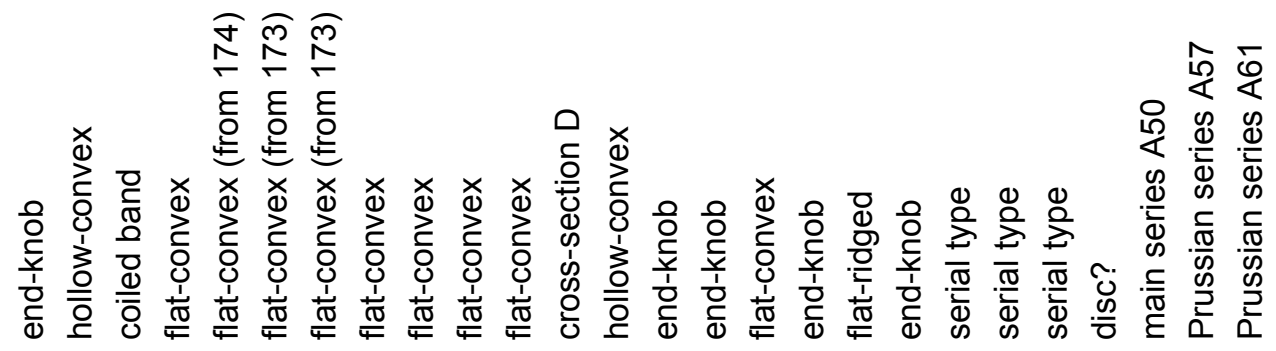

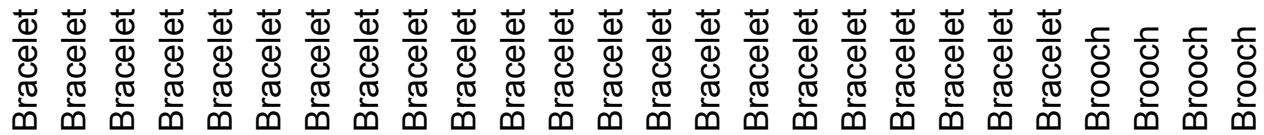

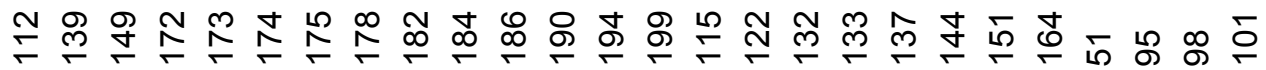

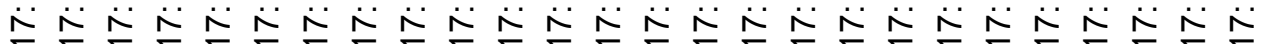

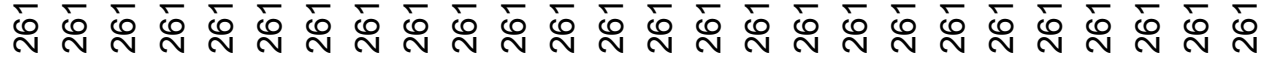

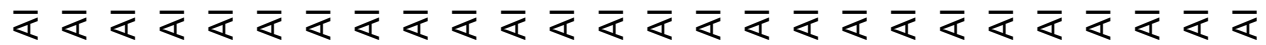




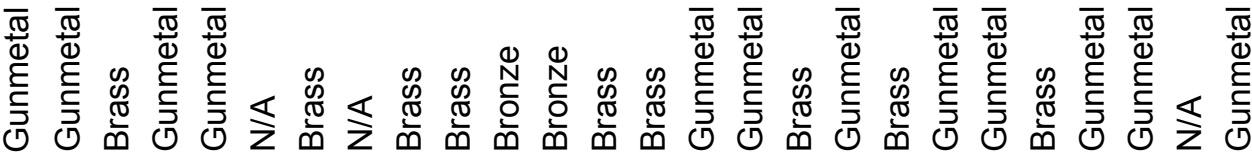

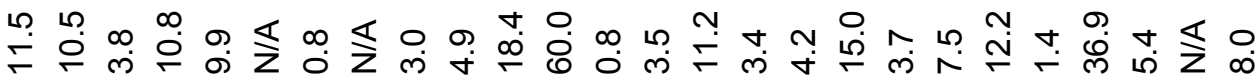

மூ

F

m 

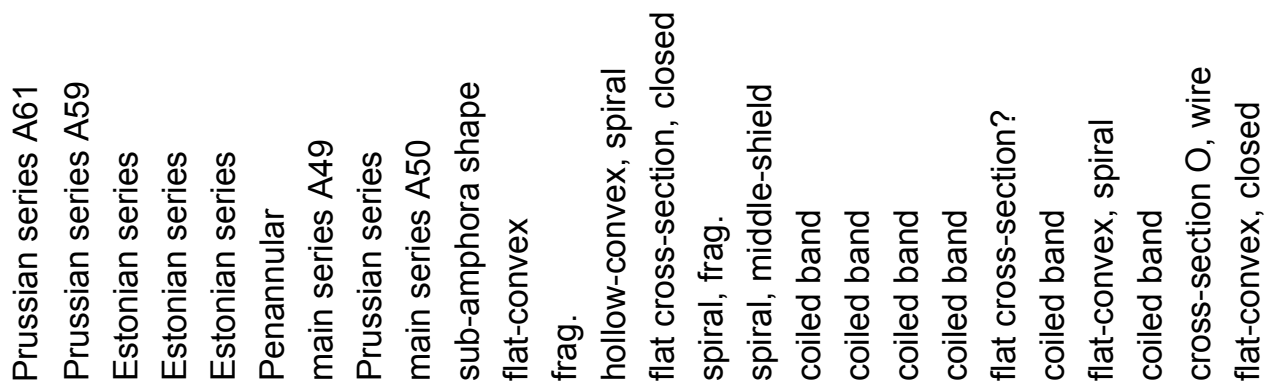

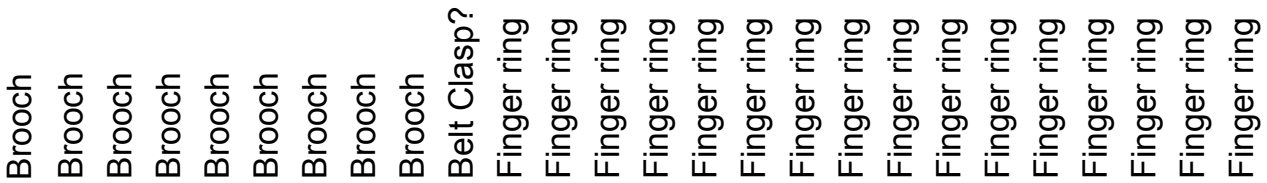

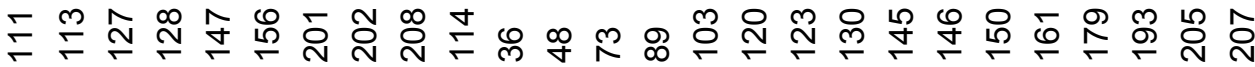

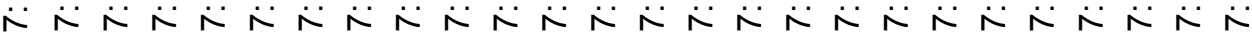

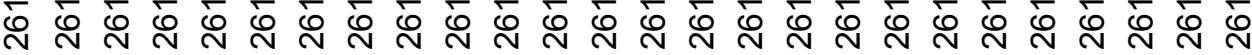

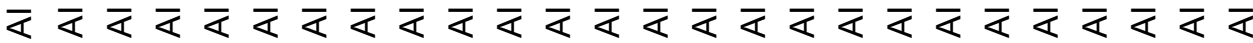




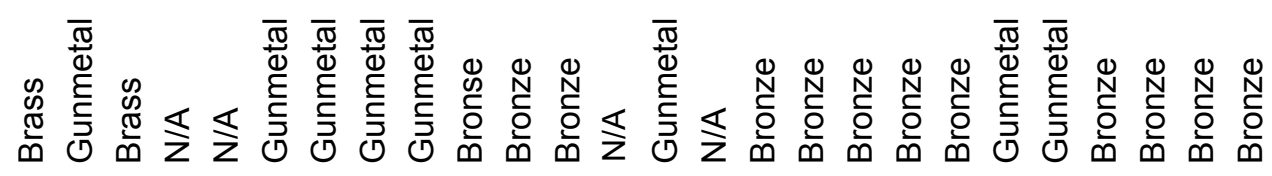

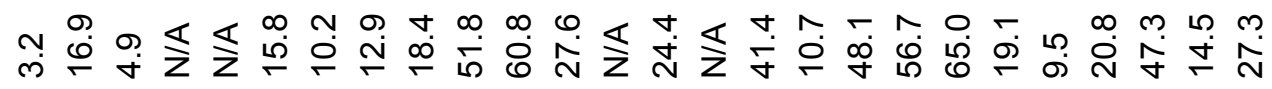
莗

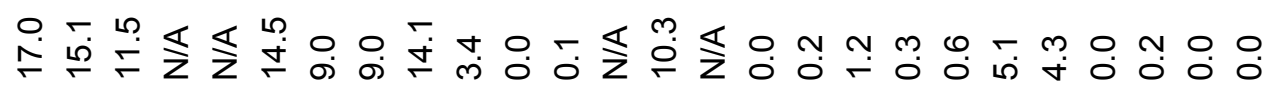

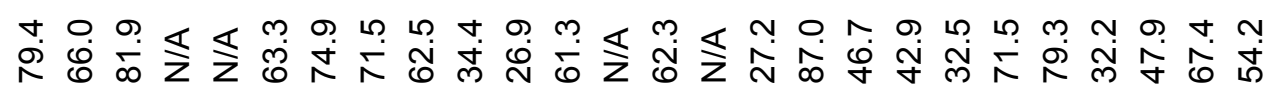

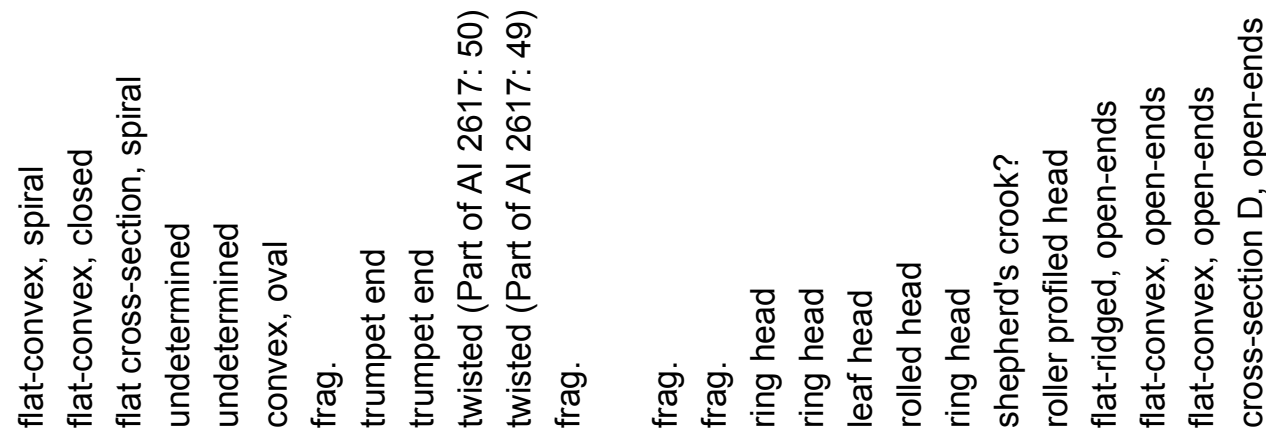

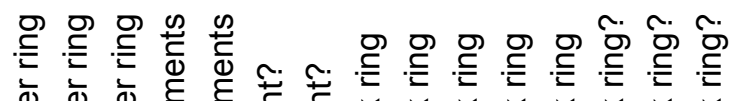

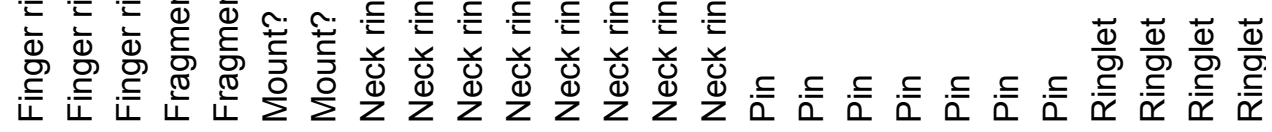
유 윤

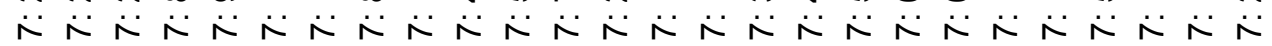

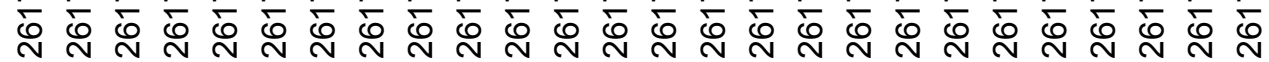

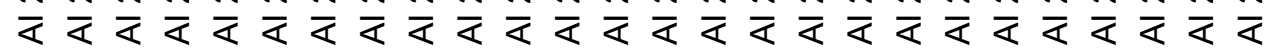




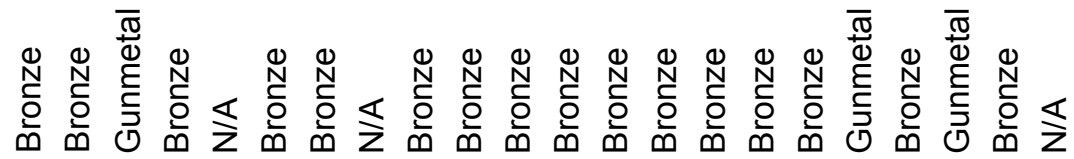

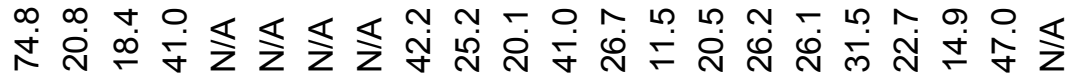

ヘิ N

虽

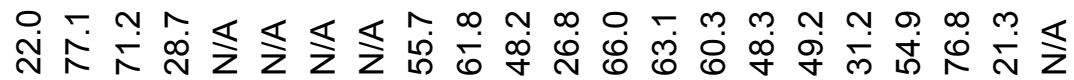

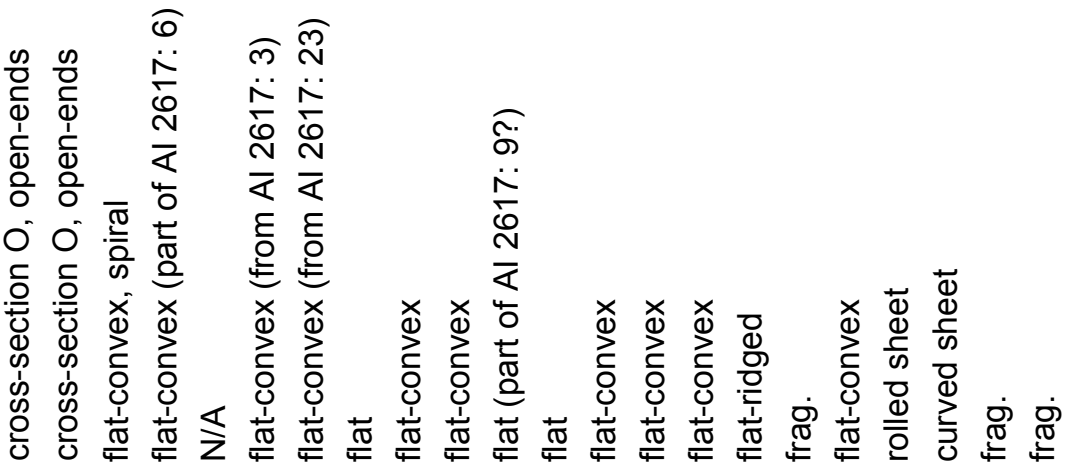

ฏ

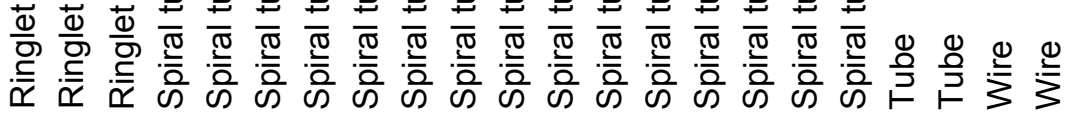

กิ

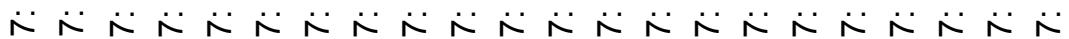

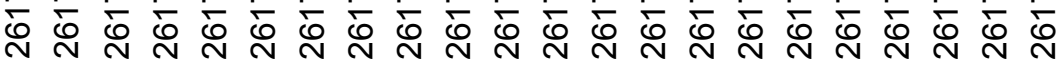

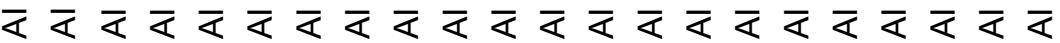




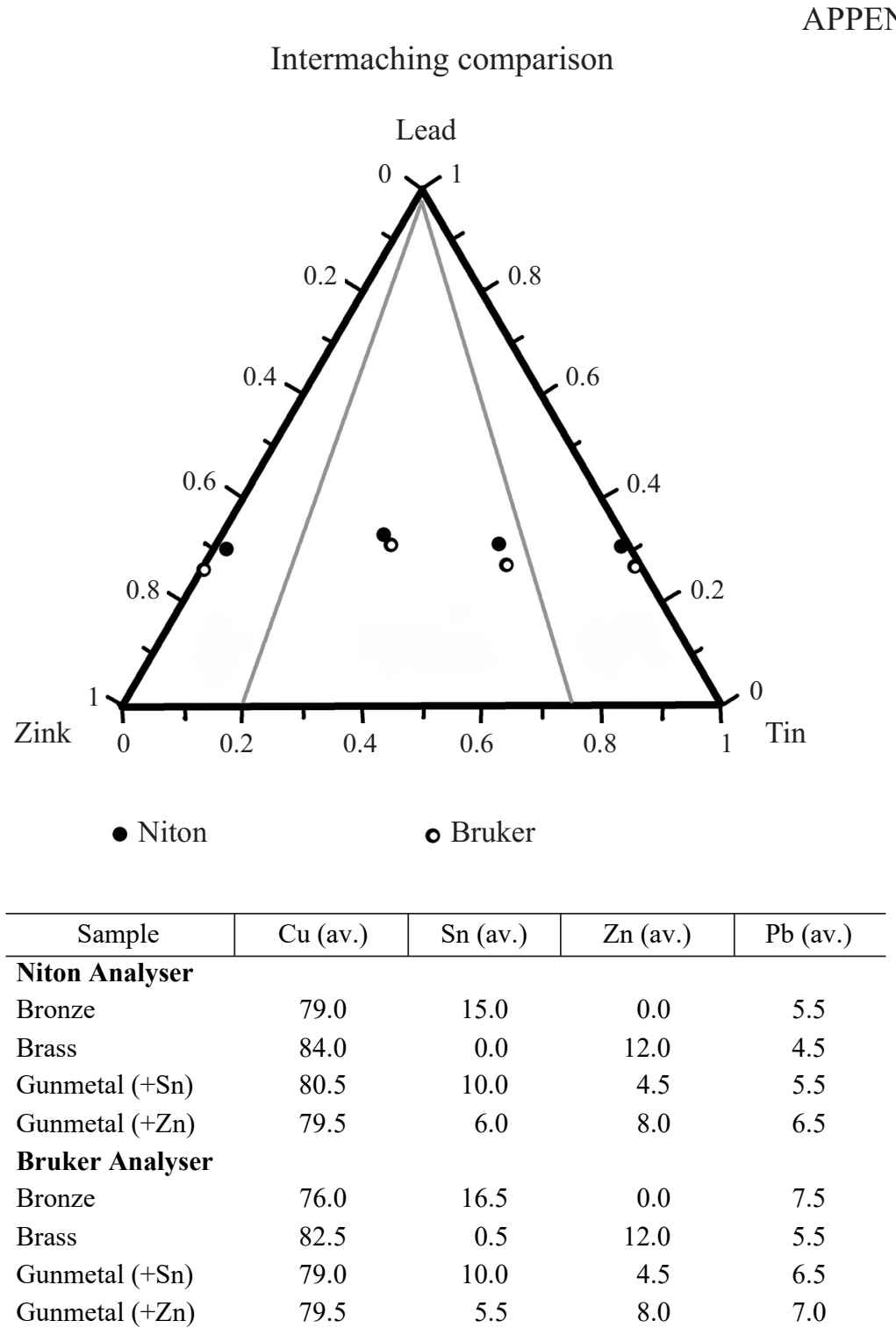

\section{References}

Almgren, O. 1897. Studien über nordeuropäische Fibelformen der ersten nachchristlichen Jahrhunderte mit Berücksichtigung der provinzialrömischen und südrussischen Formen. Stockholm. Anger, S. 1890. Das Gräberfeld zu Rondsen im Kreise Graudenz. (Abhandlungen zur Landeskunde der Provinz Westpreussen, 1.) Druck von Röthe, Danzig.

Banytė-Rowell, R., Bitner-Wróblewska, A. \& Reich, C. 2016. West Lithuania as a golden bridge between the sea and the Baltic hinterland in northeast Poland during the Roman and Migration periods. - Archaeologia Baltica, 23, 140-151. 
Baumeister, M. 2004. Metallrecycling in der Frühgeschichte. Untersuchungen zur technischen, wirtschaftlichen und gesellschaftlichen Rolle sekundärer Metallverwertung im 1. Jahrtausend n. Chr. (Würzburger Arbeiten Prähist. Arch., 3.) Leidorf, Rahden.

Bayley, J. \& Butcher, S. 2004. Roman Brooches in Britain: A Technological and Typological Study Based on the Richborough Collection. Society of Antiquaries of London, London.

Bennett, A. 1975. Nyupptäckta Svenska tarandgravar. - Fornvännen, 70, 59-67.

Bezzenberger, A. 1904. Analysen vorgeschichtlicher Bronzen Ostpreussens. Gräfe \& Unzer, Königsberg.

Bitner-Wróblewska, A. 2010. North-eastern Poland in first centuries AD, a world apart. - Worlds Apart? Contacts across the Baltic Sea in the Iron Age. Eds U. Lund Hansen \& A. Bitner-Wróblewska. Państwowe Muzeum Archeologiczne, København, 141-184.

Bitner-Wróblewska, A. \& Rzeszotarska-Nowakiewicz, A. 2016. The Balt societies in Poland, 1500 AD. - The Past Societies, 4: Polish Lands from the First Evidence of Human Presence to the Early Middle Ages. Eds P. Urbańczyk \& A. Rzeszotarska-Nowakiewicz. Polish Academy of Sciences, Warsaw, 257-306.

Bliujienè, A. 2011. Northern Gold Amber in Lithuania (c.100 to c.1200). (East Central and Eastern Europe in the Middle Ages, 450-1450, 18.) Brill, Leiden.

Bliujienė, A. 2013. Romėniškasis ir tautų kraustymosi laikotarpiai. (Lietuvos archeologija, III.) Klaipėdos universiteto leidykla, Klaipèda.

Bliujienè, A. \& Butkus, D. 2017. Roman coins in the West Lithuanian Stone Circle Graves Culture: estimated practicality or the dawn of a new phenomenon. - Interaction without Borders, Exemplary Archaeological Research at the Beginning of the 21 st Century, 1. Eds B. V. Eriksen, A. Abegg-Wigg, R. Bleile \& U. Ickerodt. Archäologisches Landesamt Schleswig-Holstein (ALSH), Schleswig, 425442 .

Bliujienė, A., Petrauskas, G., Bagdzevičienė, J., Suzdalev, S. \& Babenskas, E. 2020. Early Roman Iron Age jewellery in the northern Barbaricum. - Studies in Archaeometry. Proceedings of the Archaeometry Symposium at Norm 2019, June 16-19, Portland, Oregon, Portland State University. Dedicated to the Rev. H. Richard Rutherford, C.S.C., Ph.D. Eds M. R. Galán \& R. S. Bard. Archaeopress, Oxford, 175-217.

Blume, E. 1912. Die germanischen Stämme und die Kulturen zwischen Oder und Passarge zur römischen Kaiserzeit. (Mannus-Bibliothek, 8: 14.) C. Kapitzsch, Würzburg.

Bockius, R. \& Grabert, R. 2013. Zur kultur- und technikgeschichtlichen Stellung der Schiffsfunde aus dem Nydam-Moor (mit einem Beitrag von Rainer Grabert). Die Schiffe: Beiträge zu Form, Technik und Historie. Ed. A. Rau. (Nydam Mose, Band 4.) Aarhus University Press, Aarhus.

Caley, E. R. 1964. Orichalcum and Related Ancient Alloys: Origin, Composition and Manufacture, with Special Reference to the Coinage of the Roman Empire. (Numismatic Notes and Monographs.) American Numismatic Society, New York.

Chiavari, C., Rahmouni, K., Takenouti, H., Joiret, S., Vermaut, P. \& Robbiola, L. 2007. Composition and electrochemical properties of natural patinas of outdoor bronze monuments. Electrochimica Acta, 52, 7760-7769.

Ciglis, J. 2013. The origin of burial sites in eastern Latvia consisting of typical stone graves. Archaeologia Baltica, 19, 104-117.

Craddock, P. T. 1978. The composition of the copper alloys used by the Greek, Etruscan and Roman civilisations, 3. The origins and early use of brass. - Journal of Archaeological Science, 5, 1-16.

Dungworth, D. 1996. Caley's zinc decline reconsidered. - Numismatic Chronicle, 156, 228-234.

Gigante, G. E., Ricciardi, P. \& Ridülfi, S. 2005. Areas and limits of employment of portable EDXRF equipment for in situ investigations. - ArchéoSciences, Revue d'archéométrie, 29, 51-59.

Göbel, F. 1842. Ueber den Einfluss der Chemie auf die Ermittelung der Völker der Vorzeit, oder, Resultate der chemischen Untersuchung metallischer Alterthümer insbesondere der in den Ostseegouvernements vorkommenden, Behufs der Ermittelung der Völker, von welchen sie abstammen. Ferdinand Enke, Dorpat. 
Grane, T. 2011. Zealand and the Roman Empire: The Iron Age on Zealand. Research status and perspectives. - Nordiske Fortidsminder, serie C. Ed. L. Boye. Det Kongelige Nordiske Oldskriftselskab, Copenhagen, 101-111.

Grewingk, C. 1877. Zur Archäologie des Baltikum und Russlands, II. Beitrag uiber ostbaltische, vorzugsweise dem heidnischen Totenkultus dienende, schiffförmige und anders gestaltete grosse Steinsetzungen. - Archiv für Anthropologie, X. Braunschweig, 73-100, 297-331.

Hackman, A. 1905. Die ältere Eisenzeit in Finnland, I. Die Funde von fünf ersten Jahrhunderten n. Chr. Finnische Altertumsgesellschaft. Helsinki.

Haperen, M. C. van 2010. Rest in pieces: an interpretive model of early medieval 'grave robbery'. - Medieval \& Modern Matters, 1, 1-36.

Hausmann, R. 1896. Grabfunde aus Estland. Frans Kluge, Reval.

Heeren, S. 2009. Romanisering van rurale gemeenschappen in de Civitas Batavorum: de casus TielPassewaaij. (Nederlandse archeologische rapporten, 36.) Rijksdienst voor het Cultureel Erfgoed, Amersfoort.

Heeren, S. \& van Der Feijst, L. 2017. Fibulae Uit de Lage Landen. Private Press, Amersfoort.

Heginbotham, A., Bassett, J., Bourgarit, D., Eveleigh, C., Glinsman, L., Hook, D., Smith, D., Speakman, R. J., Shugar, A. \& van Langh, R. 2015. The copper CHARM set: a new set of certified reference materials for the standardization of quantitative X-Ray fluorescence analysis of heritage copper alloys. - Archaeometry, 57: 5, 856-868.

Kiudsoo, M. 2012. New Roman coin find in Estonia. - AVE, 2011, 289-296.

Lang, V. 2007. The Bronze and Early Iron Ages in Estonia. (Estonian Archaeology, 3.) Tartu University Press, Tartu.

Lutz, J. \& Pernicka, E. 1995. Energy dispersive X-Ray fluorescence analysis of ancient copper alloys: empirical values for precision and accuracy. - Archaeometry, 38: 2, 313-323.

Martinón-Torres, M., Li, X. J., Bevan, A., Xia, Y., Zhao, K. \& Rehren, Th. 2012. Forty thousand arms for a single emperor: from chemical data to the labor organization behind the bronze arrows of the terracotta army. - Journal of Archaeological Method and Theory, 21: 3, 534-562.

Michelbertas, M. 1997. Paragaudžio pilkapynas.Vilnius.

Moora, H. 1938. Die Eisenzeit in Lettland bis etwa 500 n. Chr. II. Teil: Analyse. Õpetatud Eesti Selts, Tartu.

Nowakowski, W. 1998. Die Funde der römischen Kaiserzeit und der Völkerwanderungszeit aus Masuren. (Museum für Vor- und Frühgeschichte, Bestandskat, 6.) Staatliche Museen zu Berlin, Berlin. Olli, M. 2019. From Individuality to Regionality in the Distribution Area of Tarand Cemeteries in the Roman Iron Age (50-450 AD). (Dissertationes archaeologiae Universitatis Tartuensis, 9.) Tartu University Press, Tartu.

Olli, M. \& Roxburgh, M. 2018. Disc brooches of the Roman Iron Age from the tarand cemeteries of Estonia and north Latvia. - Lietuvos Archeologija, 44, 39-70.

Pfeiffer-Frohnert, U. 1998. 'Mit Augen am Fuß und mit Wulst statt Scheibe.' Verbreitung und Zeitstellung der preußischen Nebenserie A57-61 und ihrer Varianten. - 100 Jahre Fibelformen nach Oskar Almgren. Internationale Arbeitstagung 25.-28. Mai 1997 in Kleinmachnow, Land Brandenburg. Ed. J. Kunow. (Forschungen zur Archäologie im Land Brandenburg, 5.) Wünsdorf, 125-134.

Pitts, L. F. 1989. Relations between Rome and the German 'Kings' on the middle Danube in the first to fourth centuries A.D. - The Journal of Roman Studies, 79, 45-58.

Pitts, M. \& Versluys, M. J. 2014. Globalisation and the Roman World; World History, Connectivity and Material Culture. Cambridge University Press, Cambridge.

Pliny the Elder, Naturalis Historiae. Ed. C. Mayhoff. Leipzig, 1897.

Pollard, A. M., Bray, P., Gosden, C., Wilson, A. \& Hamerow, H. 2015. Characterising copper-based metals in Britain in the first millennium AD: a preliminary quantification of metal flow and recycling. - Antiquity, 89, 697-713.

Potts, P. J. \& West, M. (eds) 2008. Portable X-ray Fluorescence Spectrometry: Capabilities for in Situ Analysis. RSC Publishing, Cambridge. 
Rehren, Th. 1999. Small size, large scale: Roman brass production in Germania Inferior. - Journal of Archaeological Science, 26: 8, 1083-1087.

Rehren, Th. 2002. Metallanalysen an römischen Fibeln aus der CUT. - Die Fibeln aus dem Areal der Colonia Ulpia Traiana. Xantener Berichte, 10. Ed. U. Boelicke. Phillip Von Zabern, Mainz, 146-147. Riha, E. 1990. Die römischen Fibeln aus Augst und Kaiseraugst. (Forschunghen in Augst, 10.) Amt für Museen und Archäologie des Kantons Basel-Landschaft, Liestal.

Robbiola, L., Blengino, J. M. \& Fiaud, C. 1998. Morphology and mechanisms of formation of natural patinas on archaeological Cu-Sn alloys. - Corrosion Science, 40: 12, 2083-2111.

Roxburgh, M. \& Olli, M. 2019. Eyes to the north: a multi-element analysis of copper-alloy eye brooches in the eastern Baltic, produced during the Roman Iron Age. - Germania, 96, 209-234.

Roxburgh, M., Heeren, S., Huisman, H. \& van Os, B. 2016. Early Roman copper-alloy brooch production: a compositional analysis of 400 brooches from Germania Inferior. - Journal of Roman Archaeology, 29, 411-421.

Roxburgh, M., Heeren, S., Huisman, H. \& van Os, B. 2017. De koperlegeringen van Romeinse fibulae en hun betekenis. - Fibulae uit de Lage Landen. Eds S. Heeren \& L. van der Feijst. Private Press. Amersfoort, 243-258.

Roxburgh, M., Heeren, S., Huisman, H. \& van Os, B. 2018. Non-destructive survey of early Roman copper-alloy brooches using portable X-ray fluorescent spectrometry. - Archaeometry, 61: 1, 59-65. Rybakov, В. 1948. = Рыбаков Б. А. Ремесло Древней Руси. Academy of Sciences of the USSR, Moscow.

Salo, U. 1968. Die frührömische zeit in Finnland. (SMYA, 67.) Suomen Muinaismuistoyhdistys, Helsinki.

Sas, K. \& Thoen, H. (eds) 2002. Schone Schijn: Romeinse juweelkunst in West-Europa / Brillance et Prestige: la joaillerie romaine en Europe occidentale. Peeters, Leuven.

Schmiedehelm, M. 1923. Beiträge zu der sogenannten gotischen Frage im Baltikum. Sitzungsberichte der Gelehrten Estnischen Gesellschaft, 1922, 76-107.

Schmiedehelm, M. 1925. Kaevamisaruanne Lüganuse khk. End. Jäbara ms. Asuniku Jakob Tuiv’i maal asuval kalmul (n.n. "Kärrismäel"). Unpublished excavation report. Tallinn University archive.

Schmiedehelm, M. 1927. Lüganuse Jäbara Kärrismäe Kalmu C kaevamisaruanne. Unpublished excavation report. Tallinn University archive.

Schmiedehelm, М. 1955. = Шмидехелъм М. Х. Археологические памятники периода разложения родового строя на северо-востоке Эстонии (V в. до н. э. - V в. н. э.). Эстонское государственное издательство, Таллин.

Shackley, M. S. (ed.) 2011. X-Ray Fluorescence Spectrometry (XRF) in Geoarchaeology. Springer, London.

Tacitus. Germania. Ed. R. P. Robinson. Hildesheim, 1991.

Tacitus. The Annals 2.62. Eds A. J. Church \& W. J. Brodribb. New York, 1942.

Tate, J. 1986. Some problems in analysing museum material by non-destructive surface sensitive techniques. - Nuclear Instruments and Methods in Physics Research Section B: Beam Interactions with Materials and Atoms, 14: 1, 20-23.

Voss, H.-U. 2008. Fremd, nützlich, machbar. Römische Einflüsse im germanischen Feinschmiedehandwerk. - Zwischen Spätantike und Frühmittelalter. Archäologie des 4. bis 7. Jahrhunderts im Westen. Ergbd. RGA 57. Ed. S. Brather. Walter de Gruyter, Berlin, 343-365.

Witcher, R. 2017. The globalized Roman world. - The Routledge Handbook of Globalization and Archaeology. Ed. T. Hodos. Routledge, Abingdon, 634-651.

Zapolska, A. 2011. Roman coins from the western part of the West Balt territory. - Proceedings of the XIVth International Numismatic Congress, Glasgow 2009. Ed. N. Holmes. International Numismatic Council, Glasgow, 1115-1125.

Zapolska, A. 2013. The influx of Roman coins to the West Balt culture environment. - Notae Numismaticae, VIII, 105-123. 


\title{
Marcus Adrian Roxburgh
}

\section{AJAMASINAD: ÜHELT EESTI TARANDKALMISTULT LEITUD ROOMA RAUAAJA VASESULAMIST ESEMETE UURIMINE pXRF-i ABIL}

\begin{abstract}
Resümee
On käsitletud uut moodust, iseloomustamaks roostetanud vasesulamist esemeid, kasutades pXRF-meetodit. Rakendati mittedestruktiivset meetodit esemetel, mis leiti rooma rauaaja tarandkalmistult Kirde-Eestist. Ühe hoolikalt valitud eseme puhul kasutati destruktiivset analüüsi. Eesmärk oli uurida kalmistu kronoloogilist arengut, pöörates tähelepanu nii traditsioonilistele arheoloogilistele andmetele kui ka ajalooliselt tuntud muudatustele sulami koostises. Tõstatati küsimus, kas pXRFanalüüs suudab aidata meil mõista kronoloogilist muutust rooma rauaaja tarandkalmistul.

Kvalitatiivse (mittedestruktiivse) lähenemise tulemused Jäbara C kalmistu ainesel näitasid selget ruumilist jaotust pronksist, messingist ja punapronksist tehtud esemete vahel. $88 \%$ pronksesemeid asusid kivikirstkalmete ja varaste tarandite ümber. See kinnitab kalmistu rooma rauaaja eelse osa dateeringut, kuna messing ei olnud sulamisse veel ilmunud.

Vasest ja punapronksist esemed aga seostusid hilisemate rooma rauaaja struktuuridega. 94\% punapronksist esemeid võis kindlalt seostada hilisema piirkonnaga, tüüpiliste tarandite alaga. Siiski olid messingist ja punapronksist esemed omavahel mõnel määral segatud, ilmselt kalme ala pikaajalise kasutuse tõttu.

Silmiksõlgede koostis kinnitas varem avaldatud analüüse. Varasemad messingist põhisarja sõled vastasid 1. sajandi päritolule, samas kui Preisi sari (punapronks) vastas hilisemale, 2. sajandile. Leiukohtade osas aga ei olnud ruumilist jaotust. Põhjuseks võib olla see, et kalmistu oli mõlema sajandi jooksul kasutuses.

Kõik seeriakäevõrud olid tehtud pronksist, mis tähendab, et need valmistati enne, kui messing ilmus matuseesemetesse, või siis seda, et pronksi kasutati kauem. Nende leiukohad kattusid enamjaolt eelrooma rauaaegsete tarandite alaga. Üksikud leiud eraldusid seeriagruppidest, osutades hilisematele vahelesegamistele, näiteks varaste tarandite ala kivide taaskasutamine kalmistu hilisematel etappidel või vähemalt materjali röövimine sellelt üleminekualalt.

Kõik nuppotstega käevõrud olid tehtud puhtast messingist, kuna roostetanud välispinnal ei olnud peaaegu üldse tina. See võimaldas määrata tootmiseks küllaltki laia ajavahemiku, 1. sajandi lõpp eKr ja 1. sajand pKr, mis põhineb sesterts-müntide sulamil. Enamik käevõrusid (75\%) asus kalmistu varaste tarandite osas. Kolm käevõru leiti silmiksõlgede lähedusest ja võivad nendega seotud olla, kuna seda tüüpi käevõrud toodi sisse ning ringlesid Eestis silmiksõlgedega samal ajal. Koostisained aga viitavad, et need ringlesid väga vara.

Avispää käevõru kvantitatiivse (destruktiivse) proovi tulemused osutasid tootmisajale 1. sajandi keskpaigast eKr kuni 1. sajandi keskpaigani pKr. Tsingi sisaldus
\end{abstract}


on väga suur (vastupidiselt vähesele tina- ja seatinasisaldusele) ja seda saab võrrelda roomlaste tootmisega näiteks müntide või sõjavarustuse puhul, aga mitte niivõrd kaubandusliku tootmisega.

Nuppotsaga käevõrusid saab seostada Preisi sarja sõlgede ilmumisega Eestis. Arvukalt samasuguseid käevõrusid on leitud põhjapoolsetes Rooma provintsides, nii et kõige tõenäolisemalt jõudsid need Kirde-Eesti rannikule Rooma ala piirilt kas siis ekspordiks mõeldud toodetena või esemetena, mis olid algselt valmistatud germaanlastest Rooma sõduritele, kes tõid need pärast oma teenistuse lõppemist koju. See hüpotees sobib ideega Rooma riiklikust tootmisest, sest see sisaldab ka toodangut põhjapoolse piiri ääres paiknevatest leegionäride töökodadest. Ajaliselt paigutub Avispää käevõru 1. sajandi esimesse poolde, mis on Eestis hiline eelrooma rauaaeg, aga see sobib ka hästi peamise seeriakäevõrude perioodiga Barbaricumis.

Igal juhul jõudsid Kirde-Eestis elavate inimesteni Visla suudmeala käevõrud ja sõled. Mõned esemed saabusid ilmselt Visla alale kui vahetuskaup merevaigu vastu ja rändasid põhja poole Eestisse järgmiseks vahetuskaubaks. Kuna merereis võttis ainult mõne nädala, olid võimalikud hooajalised (või vähemalt regulaarsed) kaubareisid, võib-olla selleks, et vahetada põllumajanduslikke ülejääke vasesulami vastu. 